\title{
Proposal for a revised classification of the Demospongiae (Porifera)
}

Christine Morrow ${ }^{1}$ and Paco Cárdenas ${ }^{2,3^{*}}$

\begin{abstract}
Background: Demospongiae is the largest sponge class including $81 \%$ of all living sponges with nearly 7,000 species worldwide. Systema Porifera (2002) was the result of a large international collaboration to update the Demospongiae higher taxa classification, essentially based on morphological data. Since then, an increasing number of molecular phylogenetic studies have considerably shaken this taxonomic framework, with numerous polyphyletic groups revealed or confirmed and new clades discovered. And yet, despite a few taxonomical changes, the overall framework of the Systema Porifera classification still stands and is used as it is by the scientific community. This has led to a widening phylogeny/classification gap which creates biases and inconsistencies for the many end-users of this classification and ultimately impedes our understanding of today's marine ecosystems and evolutionary processes. In an attempt to bridge this phylogeny/classification gap, we propose to officially revise the higher taxa Demospongiae classification.
\end{abstract}

Discussion: We propose a revision of the Demospongiae higher taxa classification, essentially based on molecular data of the last ten years. We recommend the use of three subclasses: Verongimorpha, Keratosa and Heteroscleromorpha. We retain seven (Agelasida, Chondrosiida, Dendroceratida, Dictyoceratida, Haplosclerida, Poecilosclerida, Verongiida) of the 13 orders from Systema Porifera. We recommend the abandonment of five order names (Hadromerida, Halichondrida, Halisarcida, lithistids, Verticillitida) and resurrect or upgrade six order names (Axinellida, Merliida, Spongillida, Sphaerocladina, Suberitida, Tetractinellida). Finally, we create seven new orders (Bubarida, Desmacellida, Polymastiida, Scopalinida, Clionaida, Tethyida, Trachycladida). These added to the recently created orders (Biemnida and Chondrillida) make a total of 22 orders in the revised classification. We propose the abandonment of the haplosclerid and poecilosclerid suborders. The family content of each order is also revised.

Summary: The deletion of polyphyletic taxa, the use of resurrected or new names for new clades and the proposal of new family groupings will improve the comparability of studies in a wide range of scientific fields using sponges as their object of study. It is envisaged that this will lead to new and more meaningful evolutionary hypotheses for the end-users of the Demospongiae classification.

Keywords: Taxonomy, Systematics, Sponges, Lithistids, Heteroscleromorpha, Polyphyletic, Monophyletic, Type taxon

\footnotetext{
* Correspondence: paco.cardenas@fkog.uu.se

${ }^{2}$ Department of Organismal Biology, Division of Systematic Biology,

Evolutionary Biology Centre, Uppsala University, Norbyvägen 18D, 75236

Uppsala, Sweden

${ }^{3}$ Department of Medicinal Chemistry, Division of Pharmacognosy, BioMedical

Centre, Husargatan 3, Uppsala University, 75123 Uppsala, Sweden

Full list of author information is available at the end of the article
}

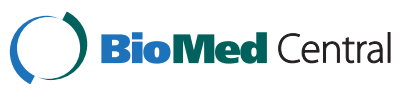

(c) 2015 Morrow and Cárdenas; licensee BioMed Central. This is an Open Access article distributed under the terms of the Creative Commons Attribution License (http://creativecommons.org/licenses/by/4.0), which permits unrestricted use, distribution, and reproduction in any medium, provided the original work is properly credited. The Creative Commons Public Domain Dedication waiver (http://creativecommons.org/publicdomain/zero/1.0/) applies to the data made available in this article, unless otherwise stated. 


\section{Background}

The Systema Porifera (SP) [1] was the result of a collaboration of 45 researchers from 17 countries led by editors J. Hooper and R. W. M. van Soest. This milestone publication in 2002 provided an updated comprehensive overview of sponge (Porifera) systematics, the largest revision of this group (from genera, subfamilies, families, suborders, orders and class) since the start of spongiology in the mid-19th century. Because before 2002 only a handful of sponge molecular studies were available, the classification of SP is largely based on sponge morphology and re-evaluation of type material, thus providing "a sound platform for the future development of sponge systematics". Since then, an increasing number of molecular phylogenetic studies have considerably shaken the taxonomic framework of SP (for a review, see [2]) especially concerning the Demospongiae. This is the largest class and includes about $81 \%$ of all living sponges with nearly 7,000 species and more than 50 new species on average described every year [3,4].

One of main reasons that molecular results contradict traditional taxonomy may be that this classification was essentially based on the morphology and arrangement of spicules, characters which have repeatedly been shown to be highly homoplasic in demosponges (i.e. prone to convergent evolution and secondary loss) [5-8]. 13 years after SP, the various molecular studies have greatly challenged the Demospongiae classification, telling a largely congruent story where numerous polyphyletic groups have been revealed or confirmed and new clades have been identified. And yet, despite a few taxonomic changes (see Cárdenas et al. [3], p. 159 for a review of these changes), the overall framework of SP classification still stands and is mirrored in the World Porifera Database (WPD, http://www.marinespecies.org/porifera). This is the most widely used reference for sponge nomenclature and part of the World Register for Marine Species (WoRMS). This has led to a widening phylogeny/classification gap which creates biases and inconsistencies for the many end-users of this classification (biochemists, microbiologists, ecologists, conservationists, paleontologists, developmental biologists) and ultimately impedes our understanding of today's marine ecosystems and evolutionary processes. In an attempt to bridge this phylogeny/classification gap, the studies of Morrow et al. [5,9] in particular, but also Redmond et al. [10] and the review of Cárdenas et al. [3] started to anticipate and suggest a revised higher taxa classification of Demospongiae. Indeed, we still have too few demosponge taxa sequenced to generate a full revision of Demospongiae classification to genus level, but we do have enough taxon coverage to suggest revisions of the higher taxa. The last sentence of the SP preface [1] states: "The Systema Porifera project is not an end - but a sound beginning for this new generation to build on what we propose here". We consider it timely to build on the SP classification and officially propose a revised classification of Demospongiae.

\section{Discussion}

\section{Revising the classification}

The SP questioned the validity of the subclasses Ceractinomorpha and Tetractinomorpha [11], based on different reproductive strategies. Since then, the polyphyly of the Ceractinomorpha and Tetractinomorpha has been repeatedly confirmed by molecular data. Instead, four well separated Demospongiae clades were identified, often designated under the G1, G2, G3 and G4 clades sensu Borchiellini et al. [12]. Since then, these four clades have been considered subclasses and have been named: Keratosa (G1), Myxospongiae (=Verongimorpha) (G2), Haploscleromorpha (G3) and Heteroscleromorpha (G4) [3]. Ceractinomopha and Tetractinomorpha are now officially unaccepted by WPD, but the new four subclasses are not currently implemented in WPD. In this paper, we essentially revisit the current demosponge subclasses, orders and suborders by i) highlighting polyphyletic taxa and the corresponding names that should be abandoned, ii) creating new orders for the newly identified clades and iii) reallocating families to what we believe is their correct order. Doing so, we propose a revised classification of Demospongiae, essentially based on the latest molecular results. To fit the Linnaean rank-based nomenclature, seven new orders (all within the Heteroscleromorpha) have been created to accommodate new groupings of families: Bubarida ord. nov., Desmacellida ord. nov., Polymastiida ord. nov., Scopalinida ord. nov., Clionaida ord. nov., Tethyida ord. nov., and Trachycladida ord. nov.. Other orders not present in SP are upgraded from SP suborders (Spongillida) or resurrected (Axinellida, Merliida, Suberitida, Tetractinellida). Seven SP orders are maintained (Agelasida, Chondrosiida, Dendroceratida, Dictyoceratida, Haplosclerida, Poecilosclerida, Verongiida) and two recently created orders are also included (Chondrillida, Biemnida). Although the naming of orders is not governed by the International Code of Zoological Nomenclature (ICZN), the tradition is to follow a similar rule as for the naming of families (ICZN articles 29.1 and 29.2): adding the suffix -ida to the stem of a genus name (P. Bouchet, pers. comm.). When the genus' stem ends in -ia, this makes an order name ending in -iida which explains why we decided to modify the names of Verongiida and Chondrosiida from their original spelling with one ' $i$ '. We have revised the diagnoses of resurrected orders or orders whose content has changed, by revisiting their morphological and chemical characters. We are well aware that some new definitions might appear too wide, due to the fact that we currently lack morphological synapomorphies for these new clades. For taxa where the morphological characters are 
ambiguous and molecular data are lacking we have used the qualifier 'incertae sedis' when allocating them to a particular higher taxa. To avoid the creation of 'orphan' taxa and in order to anticipate the genera re-allocations that will ensue from this proposal, we include a table of Heteroscleromorpha genera (Appendix) with tentative order and family allocations within the framework of our proposal, based on SP and molecular results. We have highlighted where there is supporting molecular data for this allocation and particularly where there is molecular data for the type taxon (Appendix). The allocations of some of the genera are likely to change in the future but we consider this table as a working hypothesis and the necessary first step for the future revision of sponge families and genera. Because of a lack of combined morphological/molecular approaches in Keratosa, Verongimorpha and Haplosclerida sensu stricto, the genera content of their families remains to this day unchanged (and is therefore not reviewed in Appendix). Figure 1 represents the Systema Porifera Demospongiae classification. Crossed out in red are names that should be abandoned. Figure 2 represents our proposal for a revised Demospongiae classification. Relationships reflect the current knowledge of molecular phylogenetics, resulting from markers 18S, 28S, CO1 (cytochrome oxidase subunit 1 , usually the Folmer fragment) and almost complete mitochondrial (mt.) genomes. In Figure 2, we have also flagged with an asterisk "*' all the families that are suspected to be non-monophyletic in order to help future systematic studies target problematic groups in need of revision and alert end-users to where contradictory results may arise.

\section{Three versus four subclasses}

One of the main discordant points among sponge taxonomists and the higher taxa may be this one: should we create three subclasses (Verongimorpha, Keratosa and Heteroscleromorpha - including the Haplosclerida) or four (Verongimorpha, Keratosa, Haploscleromorpha and Heteroscleromorpha)? The four subclasses classification originates from the first Demospongiae molecular study which named four distinct clades: G1 to G4 [12]. So the issue is whether marine Haplosclerida can be considered part of the Heteroscleromorpha or not and for this, we should first look at molecular studies with the widest taxon sampling which are those issuing from the Porifera Tree of Life (PorToL) project $[10,13]$, and then at those with the highest number of characters; the $\mathrm{mt}$. genome studies of Lavrov et al. [14]. $18 \mathrm{~S}$ suggests there are four clades with strong support ( $>90$ bootstrap support (b.s.)), marine Haplosclerida and Heteroscleromorpha group with moderate support (70 b.s.) [10]. $28 \mathrm{~S}$ and mt-genome phylogenetic analyses also find the same four strongly supported clades but this time marine Haplosclerida and Heteroscleromorpha group with a stronger support of 90 b.s. [13-15]. So current molecular data support either three or four subclasses. But skeleton morphology favours three subclasses since Verongimorpha and Keratosa do not have (for the most part) siliceous spicules, and especially do not share the diversity of microscleres present in Heteroscleromorpha and Haplosclerida. By choosing three subclasses we can restrict the order Haplosclerida to the marine Haplosclerida and include it in the Heteroscleromorpha, which becomes by far the largest Demospongiae subclass.

\section{Deleting polyphyletic groups \\ Abandoning the subclasses Tetractinomorpha and Ceractinomorpha}

Tetractinomorpha and Ceractinomorpha are a legacy from the works of Lévi $[16,17]$ that tentatively grouped sponges according to their modes of reproduction (oviparous vs. ovoviviparous). Although early morphological cladistic analysis suggested the polyphyly of these subclasses $[18,19]$, SP followed the classification of Lévi [20] and subdivided the class Demospongiae into three subclasses: Tetractinomorpha, Ceractinomorpha and Homoscleromorpha. The Homoscleromorpha will not be considered here as it was removed from the Demospongiae and is now accepted as a separate sponge class [21]. Shortly after the publication of SP, molecular studies confirmed the polyphyly of Tetractinomorpha and Ceractinomorpha [12,22]. The abandonment of Tetractinomorpha and Ceractinomorpha was officially agreed upon during the 7th International Sponge Symposium (Búzios, Brazil, May 2006), formally published by Boury-Esnault [23] and implemented in WPD.

\section{Abandoning Halisarcida}

In SP, Chondrosiida includes four genera: Chondrilla, Thymosia, Thymosiopsis and Chondrosia. Molecular results have repeatedly suggested the polyphyly of this order with Chondrilla, Thymosia and Thymosiopsis grouping with Halisarca (only genus of Halisarcidae, and of Halisarcida) $[10,12,24]$. Meanwhile Chondrosia was either sister group of Verongiida (very well supported) with ribosomal nuclear markers $[10,12]$ or sister-group of a Verongiida + Chondrillidae clade with $\mathrm{CO}$ [25]. It was already suggested that Halisarcida should be abandoned and Halisarcidae reallocated to Chondrosiida [26], a proposal also previously made on morphological grounds [27]. The family Chondrillidae Gray, 1872 (including Chondrilla, Thymosia and Thymosiopsis) was resurrected to be associated with Halisarcidae in the new order Chondrillida [10]. Despite contradictory results (18S-28S vs. CO1) with respect to the position of Chondrosia, Redmond et al. [10] decided to abandon Chondrosiida and include the resurrected Chondrosiidae Schulze, 1877 in Verongiida. Given the inconsistencies between ribosomal markers and $\mathrm{CO} 1$ with respect to the position of Chondrosia we have decided to retain Chondrosiida 


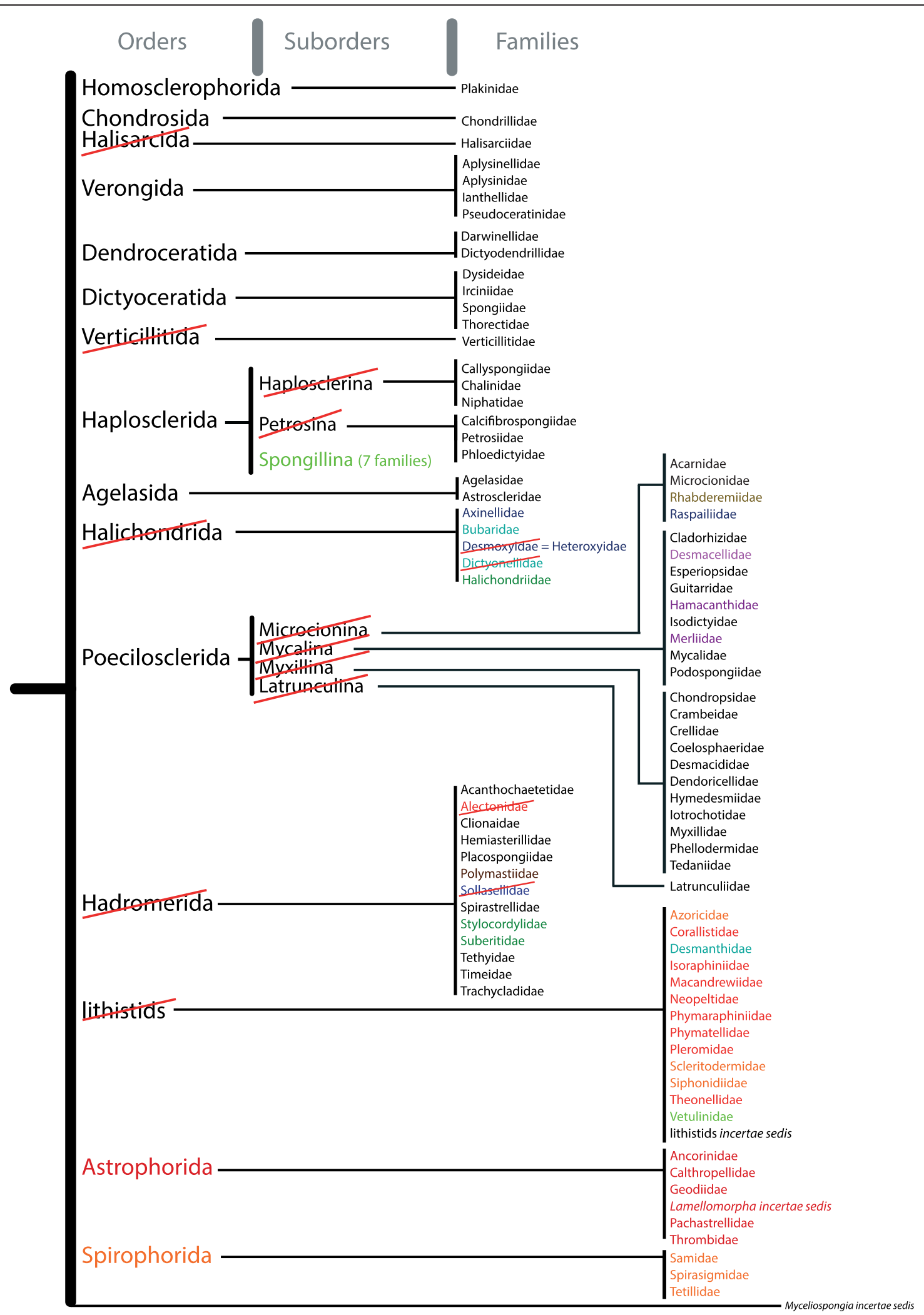

Figure 1 Demospongiae classification from orders to families, as presented in the Systema Porifera [1]. Names crossed out in red should be abandoned. Coloured names highlight taxa that should be reallocated; for their new allocation, see Figure 2 . 


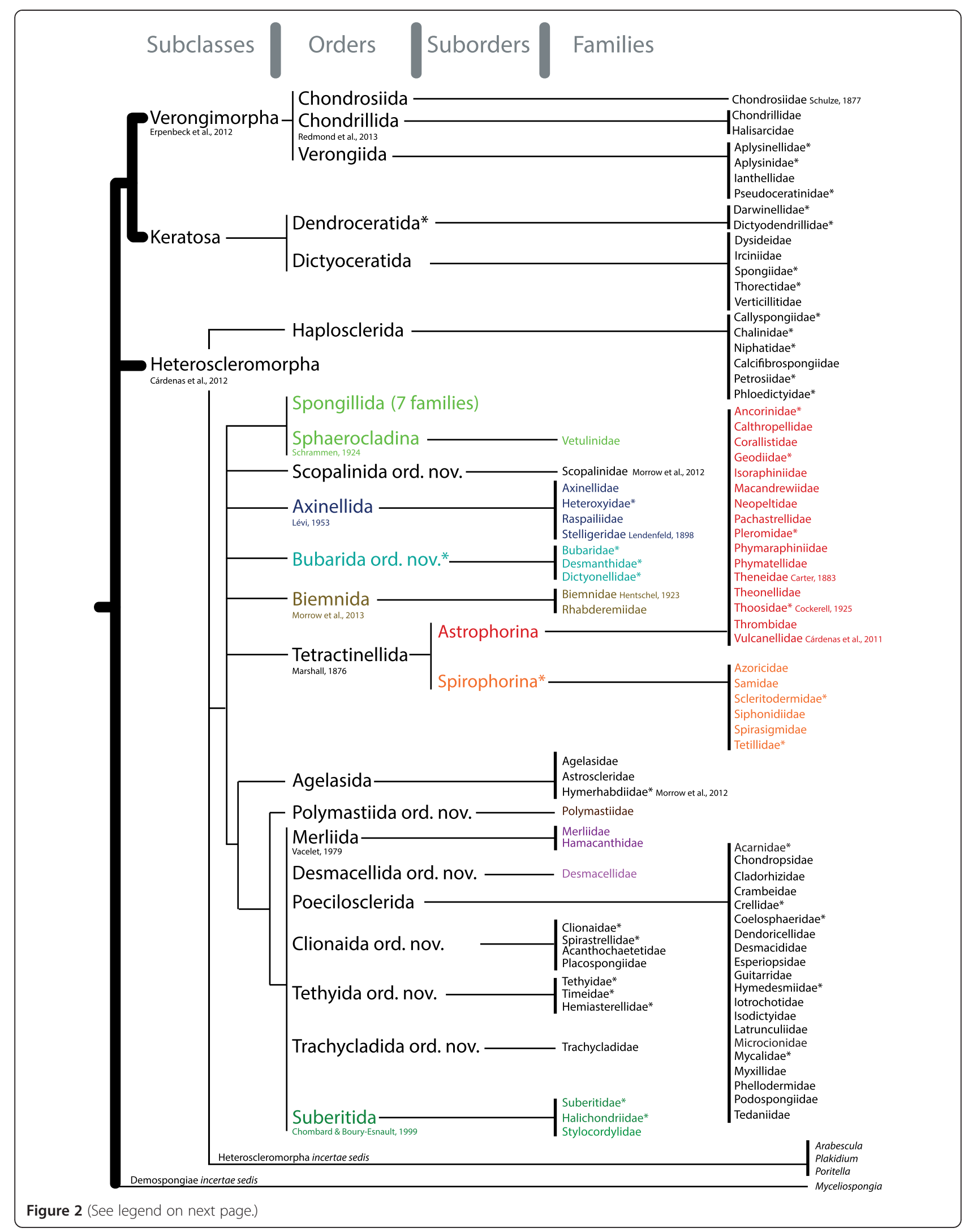


(See figure on previous page.)

Figure 2 Proposal for a revised classification of the Demospongiae, from subclasses to families. Relationships between the different taxa is deduced from all molecular phylogenetic studies published so far (as of November 2014). Coloured names correspond to the same colour code used in Figure 1. Only the authorships of new taxa or resurrected taxa since the publication of the Systema Porifera (2002) are given. An asterisk $\left(^{*}\right)$ is placed next to all order and family names suspected to be non-monophyletic, based on molecular phylogenetic results (see text for references).

with its single family Chondrosiidae and its single genus Chondrosia.

\section{Abandoning Verticillitida}

The calcified sponge order Verticillitida contains a single family Verticillitidae with a single living species: Vaceletia crypta (Vacelet, 1977). This species has no obvious morphological affinities with any Demospongiae taxa [28]. However, ribosomal and complete mitochondrial data $[29,30]$ suggested that V. crypta belonged to Dictyoceratida, making it the only Keratosa sponge with a mineral skeleton. In the WPD, the order Verticillitida has therefore been synonymized with Dictyoceratida and Verticillitidae has been included in Dictyoceratida. One should note that there are still discussions on whether $V$. crypta is related to the fossil family Verticillitidae [28,31]; it has been proposed to classify $V$. crypta in Vacelitiidae Reitner and Engeser, 1985 instead [31,32].

\section{Abandoning Spongillina, Haplosclerina and Petrosina}

In SP, Haplosclerida includes the following three suborders: Haplosclerina, Petrosina (both marine) and Spongillina (freshwater sponges) (Figure 1). The worldwide monophyletic Spongillina has been upgraded to order rank [3], since molecular results (using mt. genomes, $18 \mathrm{~S}$ and 28S) do not support its grouping with marine Haplosclerida (e.g. $[10,13,14])$. The only two phylogenetic studies disagreeing with these groupings used seven nuclear housekeeping genes (NHKG). In these two studies, the Spongillida group with the marine Haplosclerida, albeit with either no significant or relatively low support (74 b.s.) [24,33]. Furthermore, the taxonomic sampling in these studies was limited: only two species of Spongillida and no species of Vetulinidae - which may be the sister group of Spongillida $[10,34]$ - and therefore a key group that could considerably alter the topology of the NHKG trees. For the rest of Haplosclerida, often referred to as 'marine Haplosclerida', Cárdenas et al. [3] (p. 170) proposed the subclass name Haploscleromorpha. Here we abandon Haploscleromorpha and retain Haplosclerida (with a revised definition) as an order within the subclass Heteroscleromorpha (cf. discussion above on 'Three versus four subclasses').

Although Haplosclerida is a well-supported clade, the suborders Haplosclerina and Petrosina and almost every family therein appear polyphyletic (for a review see [3], p. 192; [10]). A revision of Haplosclerida using new character datasets and implementing a bottom-up approach, studying first the type species of each genus [3] within each of the 5 newly found clades - provisionally called clade A to E [10] - is urgently needed. In the meantime, we propose to abandon these suborders.

\section{Abandoning Lithistida}

Lithistida Schmidt, 1870 had been considered an artificial and polyphyletic group long before it was confirmed by molecular results. The only shared character of Lithistida is interlocked spicules called 'desmas' which form a rigid skeleton. Lithistida are easily fossilized and thus have an extremely rich fossil record in comparison with other Demospongiae. Despite their acknowledged polyphyly and after numerous debates during the SP genesis, desma-bearing demosponges were grouped together under the name "lithistid' Demospongiae", mainly for convenience (Figure 1). Even though SP proposed to abandon the order Lithistida [35], this name has remained in the WPD, which can be very misleading for end-users such as biochemists, microbiologists, ecologists or paleontologists. Now that we have molecular support concerning the phylogenetic affinities of most of the desma-bearing families $[6,36]$, we propose to formally reallocate the 13 desma-bearing families to their respective Heteroscleromorpha orders, as was already done by Cárdenas et al. $[3,6]$, and abandon the Lithistida name in WPD. 11 out of the 13 desma-bearing families should be moved to the Tetractinellida: 8 families to the Astrophorina, 3 families to the Spirophorina. The Vetulinidae are now moved to their own order Sphaerocladina (an existing order in the fossil classification) and the Desmanthidae are allocated to Bubarida ord. nov.. 'Lithistids incertae sedis' from the SP (Arabescula, Plakidium and Poritella) should now be referred to as 'Heterosclermorpha incertae sedis' (see below).

\section{Abandoning Poecilosclerida suborders: Microcionina, Mycalina, Myxillina and Latrunculina}

In SP, Poecilosclerida comprised 25 families, distributed in four suborders erected by Hajdu et al. [37]: Microcionina, Mycalina, Myxillina and Latrunculina (Figure 1). These suborders essentially rely on the presence/absence and morphology of chelae microscleres. The SP classification is based on the assumption that chelae can be used to reconstruct phylogeny because of their morphological complexity and presumed selective neutrality but it seems that 
convergent evolution has brought phylogenetic noise to this hypothesis. Although we are far from understanding the phylogenetic relationships within this large order, molecular studies (using CO1, 28S and 18S) strongly suggest that Microcionina, Mycalina and Myxillina are polyphyletic (Figure 3) $[7,10,13,38]$. We therefore propose to abandon these suborder names. Latrunculina, which only includes Latrunculiidae, seems to be monophyletic [10,38] but for consistency it is here abandoned along with the other suborders. It is not possible to provide an alternative internal phylogenetic structure for Poecilosclerida since so few taxa have yet been sequenced.

\section{Abandoning Halichondrida}

The taxonomic history of this group is long and complex (for a review, see [39]). The SP order Halichondrida contains the following five families: Halichondriidae, Axinellidae, Dictyonellidae, Heteroxyidae and Bubaridae (Figure 1). However, the monophyly of Halichondrida has never been recovered in any morphological, molecular or biochemical cladistics analyses (e.g. [5,39,40]). Halichondrida lack any unambiguous synapomorphic characters and are mainly defined on the basis of shared negative characters. Using the $28 \mathrm{~S}$ rDNA marker, Chombard [41] and Chombard \& Boury-Esnault [42] first revealed a close relationship between Halichondriidae and Suberitidae and not with other families assigned to Halichondrida. Chombard \& Boury-Esnault [42] proposed the name Suberitina for this new clade. This clade was consistently confirmed in subsequent molecular phylogenetic studies, using more taxa and additional markers (e.g. [5]) and we now consider it should be upgraded to the order rank as Suberitida. At the same time, the other Halichondrida families were distributed amongst other clades: Axinellidae and Heteroxyidae in a well-supported clade for which we use the resurrected order name Axinellida; Dictyonellidae and Bubaridae in another clade here named Bubarida ord. nov. (Figure 2). Finally, $18 \mathrm{~S}$ and $\mathrm{CO} 1$ data revealed a new clade (unnamed at this moment) grouping species of Topsentia, Petromica and Axinyssa [10,36]. Altogether, these well-established results force us to formally propose the abandonment of Halichondrida.

\section{Abandoning Hadromerida}

Hadromerida in SP included 13 families (Figure 1), two of which have now been abandoned: Alectonidae (split between Astrophorina and Clionaidae) and the Sollasellidae (now a junior synonym of Raspailiidae). Suberitidae has

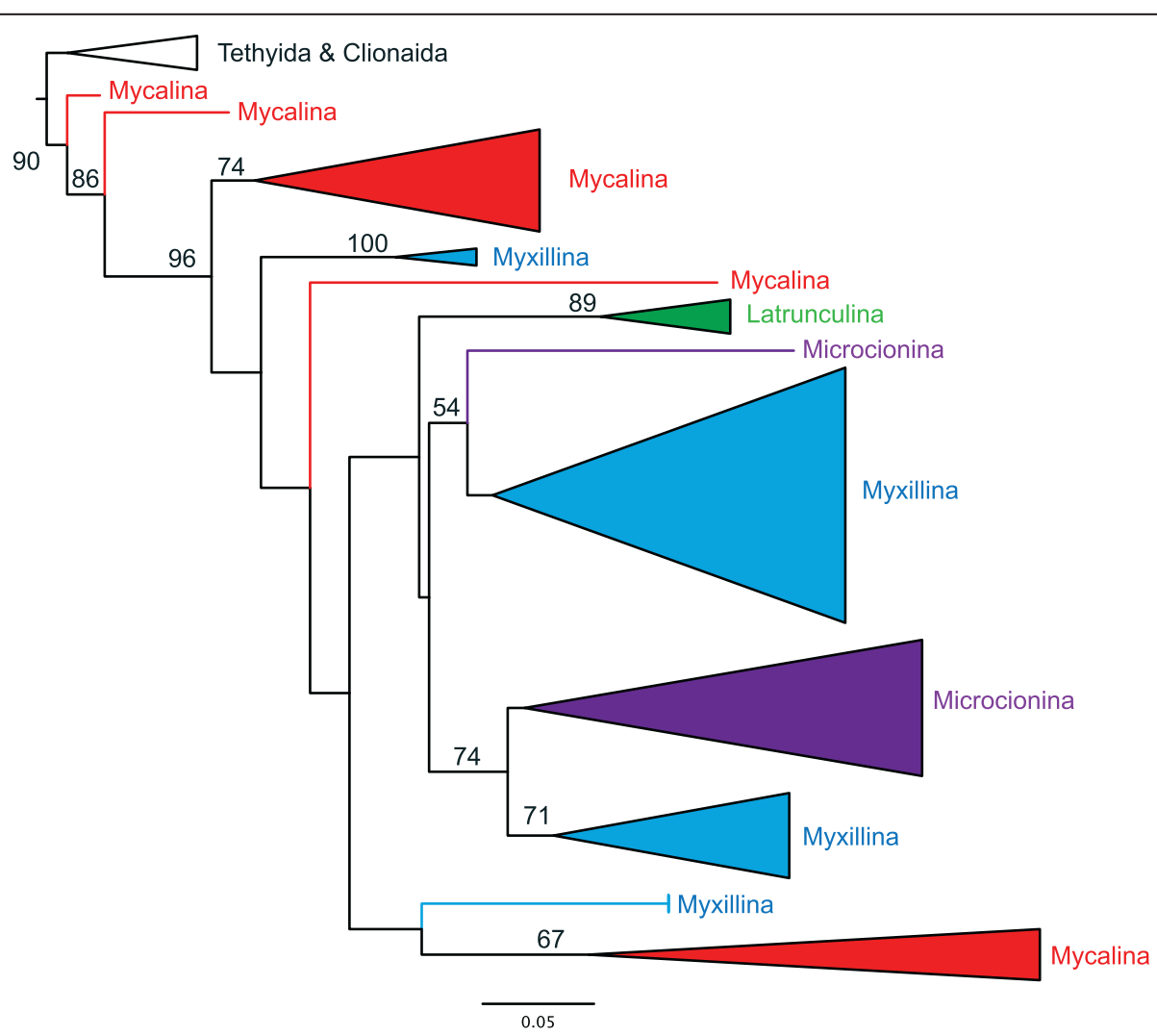

Figure 3185 tree revealing the polyphyly of the Poecilosclerida suborders. PhyML tree with branches collapsed showing the polyphyly of the poecilosclerid suborders (Microcionina, Mycalina, Myxillina), with the exception of Latrunculina; only node bootstrap support > 50 are shown. This is a subset of the data used in Redmond et al. [10]. 
often been considered as a typical 'hadromerid'. However, since the work of Chombard \& Boury-Esnault [42], Suberitidae have been shown to group with Halichondriidae in a well-supported clade. A CO1 sequence of Stylocordyla borealis suggests that Stylocordylidae, which was also considered a 'hadromerid', groups with Suberitidae and Halichondriidae (Morrow and Cárdenas, unpublished results). On the basis of $28 S$ rDNA data, Chombard [41] had anticipated that the remaining 'hadromerids' grouped in four well-supported clades, later confirmed with larger sampling and additional markers. One contains Spirastrellidae, Clionaidae, Placospongiidae and Acanthochaetetidae; a second Timeidae, Tethyidae and Hemiasterellidae (pars); a third Trachycladidae and a fourth Polymastiidae $[5,9,10,13]$. Figure 4 is an $18 S \mathrm{ML}$ tree which shows the distribution of former SP 'hadromerid' taxa relative to other Heteroscleromorpha. Lavrov et al. [14] using mitochondrial genomes showed Tethyidae grouping separately to Clionaidae but his analysis did not include Trachycladidae. Some former Hemiasterellidae have also joined some former halichondrids to group in the resurrected Stelligeridae family [5]. Altogether, given the polyphyly of Hadromerida (Figure 4) we propose the abandonment of Hadromerida, the erection of four new

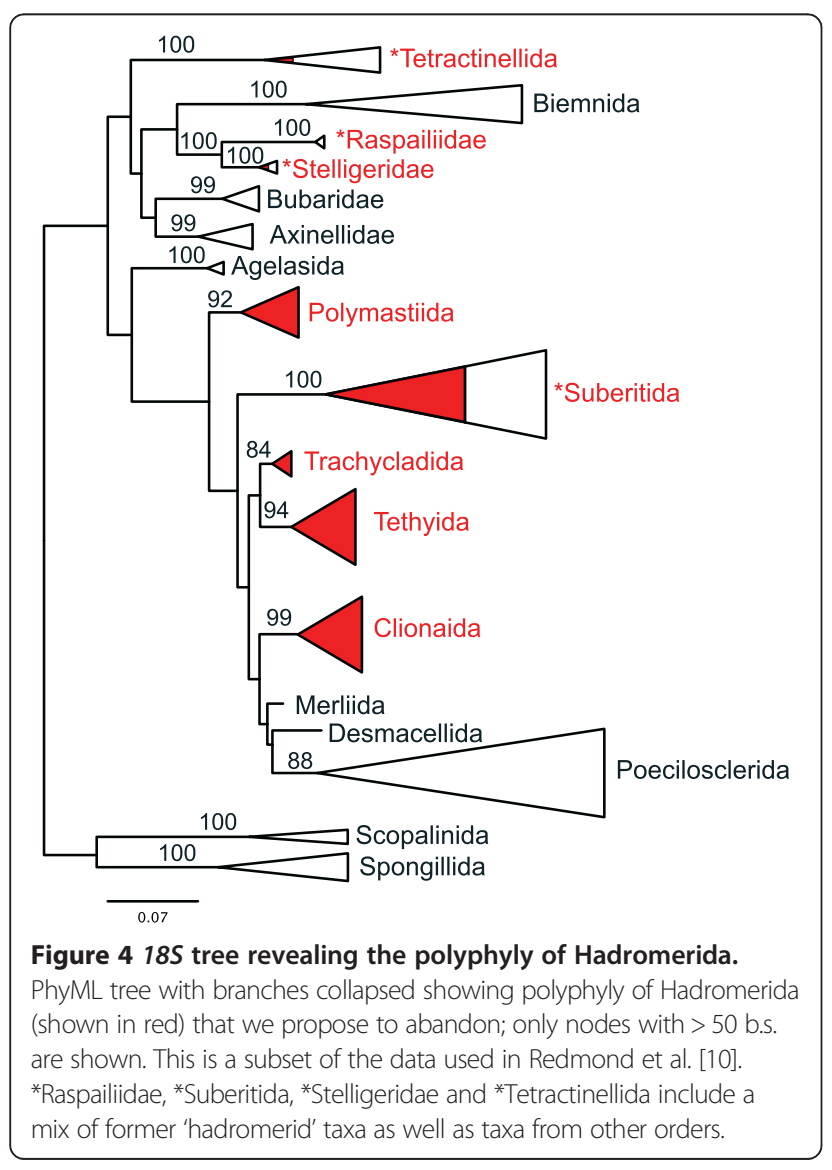

orders (Clionaida ord. nov., Tethyida ord. nov., Trachycladida ord. nov., Polymastiida ord. nov.) and the elevation of Suberitina to Suberitida Chombard \& Boury-Esnault, 1999.

\section{Taxonomy and definitions}

For the family composition of each order, see Figure 2 . For a tentative generic composition of the orders, see Appendix.

\section{Subclass Verongimorpha Erpenbeck et al., 2012}

Definition: Demospongiae without skeleton or with a skeleton made of siliceous asters (Chondrilla) or spongin fibres with a laminated bark and a finely fibrillar or granular pith (most of the Verongiida and Thymosia). Epithelial cells of the larva have i) a non-perpendicular orientation of the accessory centriole relative to the basal body, ii) a protruding nuclear apex and iii) a Golgi apparatus around the nuclear apex and part of the organelles of the basal apparatus (definition from [3], emended with larva observations from [43]).

Remark: We add here larva cytological characters in the definition but underline that very few Verongimorpha larva have been studied so far [43] so these characters need to be confirmed. Borchiellini et al. [12] resurrected Myxospongiae for their G2 clade (Halisarca + Chondrosia + Chondrillidae + Verongiida); since then, the name has been used and even erected as a subclass [43]. But Myxospongiae was originally intended for sponges without any skeleton ("ohne jedes Skelet" [44]), the so called "slime sponges" by Haeckel [44], which was essentially Halisarca. Erpenbeck et al. [25] consider that the G2 clade assemblage is too different from the original content of Myxospongiae and decide to create a replacement name for the Myxospongiae: Verongimorpha. Erpenbeck et al. [25] also consider that most of the sponges in this group are not "slime-sponges" so that the name of the subclass is not descriptive enough of the group. Myxospongiae sensu Haeckel, 1866 has been seldom used in the past and so, despite the different assemblage of Myxospongiae (G2), we believe there has not been confusion: the name Myxospongiae has been properly used now for over ten years. However, we agree that the Myxospongiae name poorly reflects the sponges it contains so we recommend using the name Verongimorpha.

Order Chondrillida Redmond et al., [10]

Definition: Verongimorpha in which the skeleton can be absent, but when present is composed of nodular spongin fibers or aster microscleres [10].

Order Chondrosiida Boury-Esnault \& Lopès, 1985

Definition: Verongimorpha with a marked ectosome or cortex enriched by a highly organized fibrillar collagen. Collagen is always very abundant. (modified from [3], p. 170). 
Remark: This order only includes the genus Chondrosia. Order Verongiida Bergquist, 1978

SP definition emended from Bergquist and Cook [45]: Verongimorpha in which the fibrous skeleton, when present, is either anastomosing or dendritic in construction. Reproduction is always oviparous. They produce complex brominated tyrosine-derived compounds.

Remark: Most relationships are uncertain within this order; Pseudoceratinidae, Aplysinellidae and Aplysinidae are probably not monophyletic $[10,13,25,46,47]$.

\section{Subclass Keratosa Grant, 1861}

Definition: Demospongiae with a skeleton made of spongin fibre. Spongin fibres are either homogenous or pithed and strongly laminated with pith grading into bark. One genus has a hypercalcified basal skeleton (Vaceletia). ([3], p. 170).

\section{Order Dendroceratida Minchin, 1900}

SP definition emended from Bergquist and Cook [48]: Keratosa in which a fibre skeleton is always present but, as compared to Dictyoceratida, is reduced in relation to soft tissue volume. The skeleton arises from a continuous spreading basal plate, and adopts either a dendritic or an anastomosing pattern. In anastomosing forms there is never any clear size distinction between primary and secondary elements. The fibres always contain pith and are strongly laminated, usually quite stout, and in some genera cellular (degenerate spongocytes) elements are incorporated in the bark and to a lesser extent in pith. Free fibrous spicules may supplement the main skeleton. The pith in the fibres is markedly disjunct from the bark, and in structure is close to that of the Verongiida. Biochemically, members of this group are characterized by a moderate sterol content in conjunction with the presence of terpenes, which are always diterpenes.

Remark: This order and both of its families (Darwinellidae and Dictyodendrillidae) may be polyphyletic $[10,12,25]$.

\section{Order Dictyoceratida Minchin, 1900}

SP definition emended from Cook and Bergquist [49]: Keratosa in which a spongin fibre skeleton is constructed on an anastomosing plan. The skeleton develops from multiple points of attachment and, except in two genera where primary fibres are absent, is organized as a hierarchy of primary, secondary and sometimes tertiary elements. Fibre construction is homogeneous lacking pith with growth laminae tightly adherent and just detectable, or pithed and strongly laminated with pith grading into bark, consecutive laminae are marked but remain adherent to each other. Pith is structurally and chemically distinct from that seen in fibres of Verongiida and Dendroceratida. One species (Vaceletia crypta) has a 'sphinctozoan' grade of organization with a chambered skeleton composed of aragonite with irregular structure, without siliceous spicules.
Remark: The families Spongiidae and Thorectidae are not monophyletic and blend essentially together; some Thorectidae should also be reallocated to the Dysideidae $[10,13,25]$.

Subclass Heteroscleromorpha Cárdenas et al., [3]

Definition: Demospongiae with a skeleton composed of siliceous spicules which can be monaxons and/or tetraxons and when they are present, microscleres are highly diversified (definition of Cárdenas et al. [3] was not modified by the inclusion of Haplosclerida).

\section{Order Haplosclerida Topsent, 1928}

Definition: Heteroscleromorpha with an isodictyal anisotropic or isotropic choanosomal skeleton; spicules are diactinal megascleres (oxeas or strongyles), smooth or spined; microscleres, if present, are sigmas and/or toxas, microxeas or microstrongyles (emended definition of Haploscleromorpha Cárdenas et al., [3]).

Remark: Five out of the six families, as well as many genera are not monophyletic [10]. The last family (Calcifibrospongiidae) is monospecific. Currently, five well-supported clades (clades A-E) are recognized [10]. The definition of Cárdenas et al. [3] has been emended here to include Janulum, formerly assigned to Raspailiidae, and now included in clade E [10].

Order Spongillida Manconi \& Pronzato, [50]

SP definition of Spongillina from Manconi and Pronzato [50]: Exclusively freshwater sponges, with megascleres consisting of oxeas or strongyles, smooth or spined, forming pauci- to multispicular tracts producing irregular to regular meshes, occasionally with large alveolate cavities (a central body cavity in one family); spongin mostly sparse; microscleres present or absent, including smooth or spined oxeas, aster-like or birotule like spicules. Four families with gemmules (resting bodies containing totipotent cells), which may contain gemmuloscleres of diverse morphology that is often diagnostic. Three families lack gemmules. Where known, reproduction is viviparous, with fully ciliated parenchymella larvae.

Remark: Malawispongiidae is polyphyletic and some taxa may need to be reallocated to Spongillidae [51]. Based on CO1, $18 S$ and ITS2 phylogenetic analyses, Spongillidae are not monophyletic $[52,53]$. The monotypic family Metschnikowiidae is a doubtful Spongillida and may need to be reallocated to the Haplosclerida. Indeed, it is endemic to the Caspian Sea, thus living in brackish water instead of freshwater; its morphological characters suggest possible affinities with Janulum [54,55], recently reallocated to Haplosclerida (clade E) [10].

\section{Order Sphaerocladina Schrammen, 1924}

SP definition of Vetulinidae emended from Pisera \& Lévi [56]: Heteroscleromorpha with acrepid polyaxial (astro- or sphaeroclone) desmas. No other megascleres or 
microscleres, only one recent family but several fossil families.

Remark: We decided to use the paleontological order name since this group has a very long and rich fossil record [56]. A sister-group relationship with Spongillida is strongly supported by $18 S$ [10,34], CO1 and $28 S$ [36].

Scopalinida ord. nov.

Definition: Encrusting, massive or erect flabellate growth forms; with smooth or conulose surface supported by prominent spongin fibres cored with styles; megascleres styles, often with telescoped ends; no ectosomal skeleton; tissue contains an unusual cell type filled with refractile granules.

Remark: This order contains only one family, Scopalinidae with genera Scopalina and Svenzea. Stylissa, a former halichondrid, is here tentatively included in this order/family (Appendix) since the type species Stylissa flabelliformis grouped within the Scopalinidae [10].

Order Axinellida Lévi, 1953 (resurrected)

Definition: Megascleres are styles or tylostyles and oxea, with acanthostyles in some genera. Surface may be smooth but is usually hispid due to projecting choanosomal styles and these may be surrounded by brushes of fine oxea, anisoxea or styles forming a specialised ectosomal skeleton. Micoscleres when present are asters, acanthoxea or raphides, usually in trichodragmata (emended from [5]). Skeleton in several species comprised of a stiff axial region, usually with abundant spongin and an outer, softer extraaxial region. Colour of living sponge is characteristically orange, yellow or dark brown.

Remark: The order Axinellida Lévi, 1953 was originally erected for the families Axinellidae and Raspailiidae [17]. In subsequent publications Lévi assigned seven other families to this order. Whilst the content of Axinellida has changed from that formally defined by Lévi (1973) [20] and Bergquist $(1967 ; 1970)[57,58]$, various molecular studies have shown Axinellida to contain three of the nine families that have been assigned to it. Most importantly the studies show that Axinella polypoides, the type taxon for Axinellidae clusters here. The principles of the ICZN for family names are based on the name-bearing type genus. Whilst at order level we are not bound by the rules of the ICZN, in keeping with the spirit of the code, we retain the name Axinellida for this order. The Raspailiidae have been moved back from Poecilosclerida to this order based on numerous molecular studies (e.g. $[9,10])$. The family Stelligeridae was resurrected by Morrow et al. [5] to include former hadromerid (Stelligera, Paratimea) and halichondrid genera (Halicnemia, Higginsia). Redmond et al. [10] using $18 S$ rDNA shows strong support for a Stelligeridae-Raspailiidae clade but no support for Stelligeridae-Raspailiidae + Axinellidae. However in Morrow et al. [9] using $18 S+28 S$, Stelligeridae-Raspailiidae + Axinellidae is a strongly supported clade. Unpublished results by
C. Morrow show that some Heteroxyidae also cluster with Axinellida.

Order Bubarida ord. nov.

Definition: Heteroscleromorpha built with monactines, diactines of different kinds and different shapes (flexuous, sinuous or vermiculiform; telescoped endings are common). Flexuous or sinuous spicules may be confined to axial skeleton or form a basal layer in encrusting forms. Monocrepidial desmas form a basal skeleton in one genus (Desmanthus).

Remark: This order is in need of taxonomic revision: early indications are that there are three clades mixing species of Acanthella, Dictyonella, Bubaris, Cymbastella, Axinyssa, Phakellia and Phycopsis [5,10]. In the future it is likely that the family Dictyonellidae van Soest, Diaz \& Pomponi, 1990 and Bubaridae Topsent, 1894 will be merged, however Dictyonellidae is retained here as a revision of the order is beyond the scope of this study. It is also possible that older family names such as Desmanthidae Topsent, 1893 may take priority over Bubaridae. The lithistid family Desmanthidae is assigned to this order since the type species Desmanthus incrustans joins this clade, based on 18S, CO1 and $28 \mathrm{~S}$ markers [5,10,59]. However, $\mathrm{CO} 1$ and $18 S$ studies also suggest that Petromica (Desmanthidae), Topsentia (Halichondriidae) and some Axinyssa (Halichondriidae) group in a very well supported clade (unnamed at the moment) outside of Bubarida [10,36], therefore Desmanthidae and Bubarida are both polyphyletic. For now we retain the family Desmanthidae pending further molecular evidence.

\section{Order Biemnida Morrow et al., 2013}

Definition: Megascleres styles, subtylostyles, strongyles, rhabdostyles, or oxeas. Spicules typically enclosed by spongin fibres. Reticulate or plumoreticulate choanosomal skeleton, axially compressed in erect forms. Extraaxial plumose skeleton usually present. Microscleres are microspined sigmas/spirosigmas, toxas, microxeas, raphides, and/or commata. Biemna and Neofibularia cause a dermatitis-like reaction when in contact with bare skin [9].

Remark: This order includes former Desmacellidae genera (Biemna, Neofibularia and Sigmaxinella), grouped in the resurrected family Biemnidae, as well as the Rhabderemiidae family with a single genus Rhabderemia. Grouping of these two families is based on molecular and morphological data, notably the possession of distally microspined "sigmas", which may not be homologous to the sigmas found in poecilosclerid sponges for example $[7,9,10,60,61]$. In SP, all these genera were in the Poecilosclerida order since they were believed to have lost their chelae.

\section{Order Tetractinellida Marshall, 1876 (resurrected)}

Definition: Heteroscleromorpha usually with radial or subradial skeletal arrangement, some genera can be endolithic. Megascleres are monactines and triaenes in various 
shapes (a synapomorphy of the order, but sometimes secondarily lost). Microscleres include sigmas, asters, sometimes with microrhabds, microxeas and raphides. Desmas are sometimes present.

Remarks: Astrophorida and Spirophorida were included in SP while Tetractinellida was not. However, all molecular studies have shown that Tetractinellida is a strongly supported clade (e.g. $[10,62])$. We propose to resurrect this order, and recommend the use of the suborders Astrophorina and Spirophorina, as previously suggested [3,5]. Many Astrophorina families and genera seem to be polyphyletic, especially due to the mingling of Ancorinidae and Geodiidae genera [6,63]. Since SP, one family was resurrected (Theneidae) and a new family was created (Vulcanellidae) [6]. Alectonidae, formerly in Hadromerida has been abandoned and the genera Alectona/Delectona/Thoosa and Neamphius have been artificially kept together in the resurrected Thoosidae, now assigned to Astrophorina, awaiting a clearer appreciation of the phylogenetic relationships of Neamphius. The genera Lamellomorpha (Astrophorida incertae sedis in SP) and Characella, are both provisionally assigned to Pachastrellidae, which makes this family polyphyletic $[6,10]$. Most of the desma-bearing demosponge families have now been assigned to this order: eight and three families are now respectively assigned to Astrophorina and Spirophorina. Studies based on COI, $18 \mathrm{~S}$ and $28 \mathrm{~S}$ suggest that Spirophorina and Tetillidae may not be monophyletic $[10,36]$. It also seems that Pleromidae and Scleritodermidae may not be monophyletic [36].

\section{Order Agelasida Hartman, 1980}

Definition: Megascleres smooth or verticillately spined styles, rhabdostyles or ocassionally oxea, no microscleres. Representatives of all families of the order produce similar pyrrole-2-carboxylic compounds, characteristically with a bromine addition [5].

Remark: The new family Hymerhabdiidae added to this order currently includes the former halichondrid Hymerhabdia and the former hadromerid Prosuberites, in addition to some former halichondrids belonging to Stylissa/Axinella/Phycopsis/Cymbastela $[5,10,64]$. The former raspailiid genera Acanthostylotella and Amphinomia are now assigned to Agelasidae [10].

Polymastiida ord. nov.

SP definition by Boury-Esnault [65]: Heteroscleromorpha with a radiating choanoskeleton and a more or less complicated cortex, the outer layer being always a palisade of ectosomal spicules (tylostyles, or oxea and/ or exotyles). Megascleres are tylostyles, subtylostyles, strongyloxeas, styles or oxeas; microscleres may include centrotylote microxeas, acanthose microxeas or raphides in trichodragmata.

Remark: This order only includes the family Polymastiidae.

Order Merliida Vacelet, 1979 (resurrected)
Definition: Megascleres are diverse (oxeas, styles, mycalostyles or tylostyles) but associated with unique microscleres (either clavidiscs or diancistra-derivatives: diancistras or cyrtancistras). Raphides, sigmas or small commata-like spicules are also present. One family contains a species with a chaetetid calcareous basal skeleton, and an outer layer of which is filled with sponge tissue and siliceous spicules.

Remarks: Vacelet [66,67] first suggested to isolate Merlia in its own order - Merliida incertae sedis - but in the SP it was included in the Poecilosclerida, based on microscleres similarities with the Biemnidae and Desmacellidae [68]. The recognition of a separate order was actually confirmed in $18 \mathrm{~S}, 28 \mathrm{~S}$ and $16 \mathrm{~S}$ phylogenetic analyses, where it branches separately from the rest of the Poecilosclerida [10,59]. CO1 phylogenetic analyses further show that Hamacantha and Desmacella branch before the poecilosclerid clade (Morrow, unpublished results). Topsent [69] was the first to suggest a close relationship between Hamacantha and Merlia based on the striking similarity between the diancistras (in Hamacantha) and the clavidiscs (in Merlia). On the basis of this molecular result and also the strong morphological affinities of the microscleres we propose to move Hamacanthidae from Poecilosclerida to Merliida.

\section{Desmacellida ord. nov.}

SP definition by Hajdu and van Soest [70]: Heteroscleromorpha with monactinal megascleres arranged in plumose bundles; microscleres sigmas and sometimes raphides.

Remark: Desmacellidae, a family without chelae, seems to diverge before the Poecilosclerida radiation [10] and is here assigned its own order. Biemna, Neofibularia and Sigmaxinella which were allocated to Desmacellidae in SP, were transferred to Biemnida [9]; the remaining genera, Desmacella, Dragmatella and Microtylostylifer, are allocated to Desmacellida. However, it should be noted that there is no molecular data for Dragmatella and Microtylostylifer species.

\section{Order Poecilosclerida Topsent, 1928}

SP definition emended from Hooper \& van Soest [71]: both fibre and mineral skeletons always show regional differentiation such that megascleres are often differentiated into distinct ectosomal and choanosomal components; microscleres include chelae (a synapomorphy for the order, but sometimes lost), sigmas and sigmancistra derivatives, and other diverse forms such as toxas, raphides, microxeas, discorhabds or spinorhabds; the order appears to be exclusively viviparous.

Remark: We propose to abandon the suborders (cf. above and Figure 3). The Poecilosclerida included 25 families in the SP, five of which we now propose to reassign to Desmacellida, Merliida, Axinellida and Biemnida. Possible polyphyletic families include Acarnidae, Mycalidae, Coelosphaeridae, Hymedesmiidae and Crellidae $[10,13]$. 


\section{Clionaida ord. nov.}

Definition: Heteroscleromorpha with tylostyle megascleres; oxeas and styloid spicules are also present in one family. Variety of microscleres including streptasters (spirasters and diplasters), amphiasters, selenasters, microxeas, microrhabds, spiral microstrongyles and derivatives. Microscleres may be lacking altogether. Calcareous basal skeleton present in one family.

Remark: Clionaidae d'Orbigny, 1851 and Spirastrellidae Ridley and Dendy, 1886 seem to mix and may thus not be monophyletic $[5,22,72]$. Since Clionaidae is an older family name, there is a chance that Spirastrellidae might become invalid in the future so we chose Clionaida over Spirastrellida (which had been suggested by Chombard [41] in her PhD thesis).

\section{Tethyida ord. nov.}

Definition: Megascleres may be styles, tylostyles or oxeas arranged in tracts ending as bouquets, at or near the surface. Microscleres are euasters, usually of two sizes.

Remark: Morrow et al. [5] showed that Hemiasterellidae is polyphyletic with some genera grouping closely with some heteroxyid and raspailiid taxa and others with Tethyidae. In the absence of molecular data from the type taxon (Hemiasterella typus) we retain Hemiasterellidae in Tethyida. Furthermore, Timeidae and Tethyidae may not be monophyletic, but molecular data on these two families is sparse $[5,10,22]$. We chose the name Tethyida for this order since we have molecular data for the type taxon of Tethyidae (Tethya aurantium) but not for the type taxons of Timeidae or Hemiasterellidae.

\section{Trachycladida ord. nov.}

SP definition of Trachycladidae by Hooper \& van Soest [73]: Heteroscleromorpha with spined vermiform spinispirae and smooth microrhabds, with a differentiated axial and extraaxial skeleton cored by oxeas, strongyles and/or (tylo-)styles.

Remark: Only one family (Trachycladidae), with 10 species, belongs to this order at the moment.

Order Suberitida Chombard \& Boury-Esnault, 1999

Definition: Heteroscleromorpha without an obvious cortex and without microscleres other than microstrongyles/oxeas; megascleres are oxeas, centrotylote oxeas, styles or tylostyles. Choanosomal skeleton usually consisting of a confused arrangement of megascleres, radial arrangement of megascleres in one family. Surface skeleton of paratangential to erect palisade of large or small megascleres. Molecular synapomorphy is a deletion of a small loop of 15 base pairs in the secondary structure of the $28 \mathrm{~S}$ D2 domain with respect to other Heteroscleromorpha (slightly emended from [42] to include Stylocordylidae).

Remark: Suberitidae and Halichondriidae are currently not monophyletic due to, for example, the grouping of Terpios with the halichondrids instead of the suberitids, or the early branching of Homaxinella with respect to the rest of the Suberitida $[5,10,13]$. The allocation of Stylocordyla to Suberitida is based on previous morphological studies (e.g.
$[74,75])$ and molecular data (CO1) (Morrow and Cárdenas, unpublished results).

Heteroscleromorpha incertae sedis may include some of the former 'lithistids' incertae sedis listed in SP, which consists of poorly known genera with rhizoclone desmas of uncertain status [76]: Arabescula, Plakidium and Poritella. Collectella is clearly a tetractinellid with phyllotriaenes that we tentatively assign to Theonellidae. Collinella has been synonymized with Discodermia (Theonellidae) in the WPD.

Myceliospongia with its single species $M$. araneosa remains Demospongiae incertae sedis, as in the SP [77], awaiting molecular data to assign it to an order.

\section{Concluding remarks}

Demospongiae in SP is comprised of 13 orders. In the present proposal, five of these order names are abandoned (Hadromerida, Halichondrida, Halisarcida, lithistids, Verticillitida) and six order names are resurrected or upgraded (Axinellida, Merliida, Spongillida, Sphaerocladina, Suberitida, Tetractinellida) and seven new orders have been erected (Bubarida, Desmacellida, Polymastiida, Scopalinida, Clionaida, Tethyida, Trachycladida). These added to the recently created orders (Biemnida and Chondrillida) make a total of 22 orders in the revised classification. We propose the abandonment of all Haplosclerida and Poecilosclerida suborders and the use of Tetractinellida suborders. Finally, we reassign many families (belonging to Hadromerida, Halichondrida, Halisarcida, Poecilosclerida, Lithistida) to new orders.

When the classification changes, so does the importance of the different groups in terms of species numbers; these numbers are reviewed for the various orders in Figure 5. According to SP, Poecilosclerida was the largest order in term of species: over 2,630 species [4, accessed on the 17th of October 2014]. By reassigning five families Poecilosclerida "loses" about 421 species (essentially Raspailiidae). However the revised Poecilosclerida remains the largest order with 2,209 species. The second largest is the revised Haplosclerida with 1,073 species, and the third largest is Tetractinellida (including 11 former lithistid families) with 1,064 species ([4], accessed on the 17th of October 2014).

The overall aim of this paper is to begin to resolve the growing discrepancy between the classification presented in SP and the body of evidence from molecular phylogenetic studies. Doing so, we hope to convince end-users to 1) abandon the use of artificial groups, and to 2) use the new/resurrected names proposed here when referring to the new Demospongiae clades. This updated classification will undoubtedly facilitate communication between endusers, reduce taxonomically biased results, and ultimately provide a better understanding of Demospongiae evolutionary history. We should however keep in mind that the groupings we propose are new phylogenetic hypotheses that will be challenged by future systematic research. 


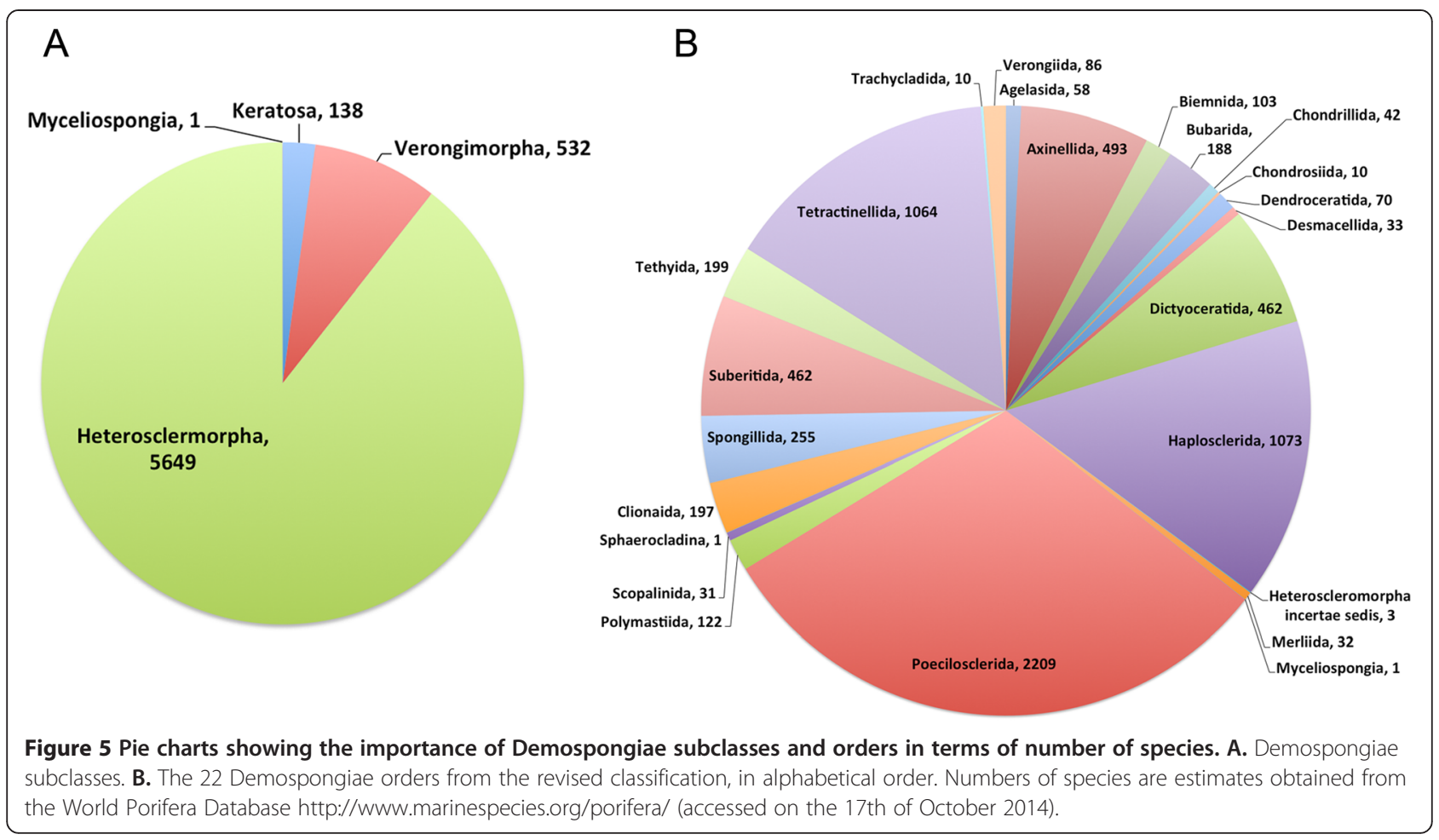

Hypotheses regarding sponge phylogenetic relationships will continue to change with the description and sequencing of new species, use of new datasets and improvements in phylogenetic reconstruction methods. New phylogenetic hypotheses will undoubtedly involve further changes to the classification. In other words, absolute nomenclatural stability in a rank-based system is impossible and name changes simply reflect the regular growth of phylogenetic knowledge and understanding [78]. This is certainly frustrating for the many end-users of the sponge classification, but it is a reality that we have to accept and understand if we want our research to rely on updated taxonomic grounds and avoid reaching misleading conclusions. The good news is that end-users and non-sponge specialists can now rely on a large choice of biodiversity web based databases. The WPD is currently the most complete, easily and regularly updated database thanks to a large editorial committee.

Yes, the Systema Porifera classification published in 2002 is already partly out of date but we should keep in mind that SP still represents a milestone for sponge researchers, due to its rigorous approach of defining terminal taxa (based on objective evidence from the type species of each genus), and the richness of taxonomic and morphological information it contains. As was certainly the case with SP, we hope the following proposal will stimulate fruitful taxonomic research. In particular, we hope this proposal will help researchers to refocus and revisit clades with a more integrative taxonomic approach [3], combining top-down and bottom-up phylogenetic strategies [3]. Many of these new groupings require clear morphological diagnoses, we hope this classification will help to reveal hidden and overlooked synapomorphies in the various datasets that sponge biologists now have at their disposal. We invite and welcome comments on our proposal, as well as any suggestions for additional changes.

\section{Appendix}

Proposal for Heteroscleromorpha genera assignments (except Haplosclerida) in their respective orders and families of the revised classification. This Table 1 lists the Heteroscleromorpha genera (in alphabetical order) with their current assignment in the World Porifera Database http://www.marinespecies.org/porifera/ (accessed on the 17th of October 2014). It does not include the marine haplosclerids as no changes are proposed for this group. For each of the genera, we give the order and family assignment within the framework of the revised classification. Some of these assignments are tentative and may change. We have included the molecular markers that exist for the type species: CO1 (cytochrome oxidase subunit 1, usually the Folmer fragment), $18 S$ (ribosomal small subunit), $28 S$ (ribosomal large subunit), ITS (internal transcribed spacer), AGL11 (aspargine-linked glycosylation 11 protein), ESTs (Expressed Sequence Tags), mt (mitochondrial genome) and tpm (transcriptome). We have also included absence/presence (yes/no) of molecular markers available for non-type species. 
Table 1 Listing of Heteroscleromorpha genera in alphabetical order

\begin{tabular}{|c|c|c|c|c|c|c|}
\hline Genus & Order & Family & $\begin{array}{l}\text { New order } \\
\text { (Suborder) }\end{array}$ & Family & Genes, type species & Genes, non-type \\
\hline Aaptos & Hadromerida & Suberitidae & Suberitida & Suberitidae & no & yes \\
\hline Abyssocladia & Poecilosclerida & Cladorhizidae & Poecilosclerida & Cladorhizidae & no & yes \\
\hline Acalle & Haplosclerida & Metaniidae & Spongillida & Metaniidae & no & no \\
\hline Acanthancora & Poecilosclerida & Hymedesmiidae & Poecilosclerida & Hymedesmiidae & 185 & no \\
\hline Acanthella & Halichondrida & Dictyonellidae & Bubarida & Dictyonellidae & $18 \mathrm{~S}, 28 \mathrm{~S}, \mathrm{COI}$ & yes \\
\hline Acantheurypon & Poecilosclerida & Raspailiidae & Poecilosclerida & $\begin{array}{l}\text { Poecilosclerida } \\
\text { incertae sedis }\end{array}$ & $18 \mathrm{~S}, 28 \mathrm{~S}, \mathrm{COI}$ & yes \\
\hline Acanthochaetetes & Hadromerida & Acanthochaetetidae & Clionaida & Acanthochaetetidae & no & yes \\
\hline Acanthoclada & Halichondrida & Heteroxyidae & Axinellida & Heteroxyidae & no & no \\
\hline Acanthopolymastia & Hadromerida & Polymastiidae & Polymastiida & Polymastiidae & no & no \\
\hline Acanthorhabdus & Poecilosclerida & Acarnidae & Poecilosclerida & Acarnidae & no & no \\
\hline Acanthostylotella & Poecilosclerida & Raspailiidae & Agelasida & Agelasidae & $18 \mathrm{~S}, 28 \mathrm{~S}$ & no \\
\hline Acanthotetilla & Spirophorida & Tetillidae & $\begin{array}{l}\text { Tetractinellida } \\
\text { (Spirophorina) }\end{array}$ & Tetillidae & no & yes \\
\hline Acanthotriaena & Astrophorida & Pachastrellidae & $\begin{array}{l}\text { Tetractinellida } \\
\text { (Astrophorina) }\end{array}$ & Pachastrellidae & no & no \\
\hline Acanthotylotra & Haplosclerida & $\begin{array}{l}\text { Spongillina incertae } \\
\text { sedis }\end{array}$ & Spongillida & $\begin{array}{l}\text { Spongillida incertae } \\
\text { sedis }\end{array}$ & no & no \\
\hline Acarnus & Poecilosclerida & Acarnidae & Poecilosclerida & AcarnidaeCP & $16 \mathrm{~S}, 18 \mathrm{~S}, 28 \mathrm{~S}$ & no \\
\hline Acheliderma & Poecilosclerida & Acarnidae & Poecilosclerida & Acarnidae & no & no \\
\hline Aciculites & 'Lithistida' & Scleritodermidae & $\begin{array}{l}\text { Tetractinellida } \\
\text { (Spirophorina) }\end{array}$ & Scleritodermidae & no & yes \\
\hline Adreus & Hadromerida & Hemiasterellidae & Tethyida & Hemiasterellidae & $18 \mathrm{~S}, 28 \mathrm{~S}, \mathrm{COI}$ & yes \\
\hline Agelas & Agelasida & Agelasidae & Agelasida & Agelasidae & $28 \mathrm{~S}, \mathrm{COI}$ & yes \\
\hline Alectona & Astrophorida & Thoosidae & $\begin{array}{l}\text { Tetractinellida } \\
\text { (Astrophorina) }\end{array}$ & Thoosidae & $\mathrm{COI}, 28 \mathrm{~S}$ & no \\
\hline Alloscleria & Halichondrida & Heteroxyidae & Axinellida & Heteroxyidae & no & no \\
\hline Amorphinopsis & Halichondrida & Halichondriidae & Suberitida & Halichondriidae & $18 \mathrm{~S}, 28 \mathrm{~S}, \mathrm{COI}, \mathrm{EF}-1$ & yes \\
\hline Amphiastrella & Poecilosclerida & lotrochotidae & Poecilosclerida & lotrochotidae & no & no \\
\hline Amphibleptula & 'Lithistida' & Scleritodermidae & $\begin{array}{l}\text { Tetractinellida } \\
\text { (Spirophorina) }\end{array}$ & Scleritodermidae & no & no \\
\hline Amphilectus & Poecilosclerida & Esperiopsidae & Poecilosclerida & Esperiopsidae & no & yes \\
\hline Amphinomia & Poecilosclerida & Echinodictyinae & Poecilosclerida & Echinodictyinae & $18 \mathrm{~S}, 28 \mathrm{~S}$ & no \\
\hline Amphitethya & Spirophorida & Tetillidae & $\begin{array}{l}\text { Tetractinellida } \\
\text { (Spirophorina) }\end{array}$ & Tetillidae & no & yes \\
\hline Anaderma & 'Lithistida' & Pleromidae & $\begin{array}{l}\text { Tetractinellida } \\
\text { (Astrophorina) }\end{array}$ & Pleromidae & no & no \\
\hline Ancorella & Astrophorida & Pachastrellidae & $\begin{array}{l}\text { Tetractinellida } \\
\text { (Astrophorina) }\end{array}$ & Pachastrellidae & no & no \\
\hline Ancorina & Astrophorida & Ancorinidae & $\begin{array}{l}\text { Tetractinellida } \\
\text { (Astrophorina) }\end{array}$ & Ancorinidae & no & yes \\
\hline Anheteromeyenia & Haplosclerida & Spongillidae & Spongillida & Spongillidae & no & no \\
\hline Anisocrella & Poecilosclerida & Crellidae & Poecilosclerida & Crellidae & no & no \\
\hline Annulastrella & Astrophorida & Theneidae & $\begin{array}{l}\text { Tetractinellida } \\
\text { (Astrophorina) }\end{array}$ & Theneidae & no & yes \\
\hline Antho & Poecilosclerida & Ophlitaspongiinae & Poecilosclerida & Microcionidae & $18 \mathrm{~S}, 28 \mathrm{~S}$ & yes \\
\hline Anthotethya & Hadromerida & Tethyidae & Tethyida & Tethyidae & no & no \\
\hline
\end{tabular}


Table 1 Listing of Heteroscleromorpha genera in alphabetical order (Continued)

\begin{tabular}{|c|c|c|c|c|c|c|}
\hline Arabescula & 'Lithistida' & $\begin{array}{l}\text { Lithistida incertae } \\
\text { sedis }\end{array}$ & incertae sedis & & no & no \\
\hline Artemisina & Poecilosclerida & Ophlitaspongiinae & Poecilosclerida & Microcionidae & no & yes \\
\hline Asbestopluma & Poecilosclerida & Cladorhizidae & Poecilosclerida & Cladorhizidae & no & yes \\
\hline Asteropus & Astrophorida & Ancorinidae & $\begin{array}{l}\text { Tetractinellida } \\
\text { (Astrophorina) }\end{array}$ & Ancorinidae & no & yes \\
\hline Astrosclera & Agelasida & Astroscleridae & Agelasida & Astroscleridae & $\begin{array}{l}\text { 28S,COI,18S, ITS1-5.8S- } \\
\text { ITS2-28S }\end{array}$ & no \\
\hline Astrotylus & Hadromerida & Polymastiidae & Polymastiida & Polymastiidae & no & no \\
\hline Atergia & Hadromerida & Polymastiidae & Polymastiida & Polymastiidae & 185 & no \\
\hline Auletta & Halichondrida & Axinellidae & Bubarida & Bubaridae $^{1}$ & no & yes \\
\hline Aulospongus & Poecilosclerida & Raspailiidae & Axinellida & Raspailiidae & no & yes \\
\hline Awhiowhio & 'Lithistida' & Corallistidae & $\begin{array}{l}\text { Tetractinellida } \\
\text { (Astrophorina) }\end{array}$ & Corallistidae & no & no \\
\hline Axechina & Poecilosclerida & Raspailiidae & Axinellida & Raspailiidae & $18 \mathrm{~S}, 28 \mathrm{~S}, \mathrm{COI}$ & no \\
\hline Axinella & Halichondrida & Axinellidae & Axinellida & Axinellidae & $18 \mathrm{~S}, 28 \mathrm{~S}$ & yes \\
\hline Axinyssa & Halichondrida & Halichondriidae & Bubarida & Dictyonellidae & 185,285 & yes \\
\hline Axos & Hadromerida & Hemiasterellidae & Tethyida & Hemiasterellidae & $28 \mathrm{~S}, \mathrm{COI}$ & yes \\
\hline Baikalospongia & Haplosclerida & Lubomirskiidae & Spongillida & Lubomirskiidae & $\begin{array}{l}\text { COI, cox2-ATP6, 18S, ITS1- } \\
\text { 5.8S-ITS2-28S }\end{array}$ & yes \\
\hline Balliviaspongia & Haplosclerida & $\begin{array}{l}\text { Spongillina incertae } \\
\text { sedis }\end{array}$ & Spongillida & $\begin{array}{l}\text { Spongillida incertae } \\
\text { sedis }\end{array}$ & no & no \\
\hline Batzella & Poecilosclerida & Chondropsidae & Poecilosclerida & Chondropsidae & no & no \\
\hline Biemna & Poecilosclerida & Desmacelliae & Biemnida & Biemnidae & $18 \mathrm{~S}, 28 \mathrm{~S}, \mathrm{COI}$ & yes \\
\hline Brachiaster & Astrophorida & Pachastrellidae & $\begin{array}{l}\text { Tetractinellida } \\
\text { (Astrophorina) }\end{array}$ & Pachastrellidae & no & no \\
\hline Bubaris & Halichondrida & Bubaridae & Bubarida & Bubaridae & no & yes \\
\hline Burtonitethya & Hadromerida & Tethyidae & Tethyida & Tethyidae & no & no \\
\hline Callipelta & 'Lithistida' & Neopeltidae & $\begin{array}{l}\text { Tetractinellida } \\
\text { (Astrophorina) }\end{array}$ & Neopeltidae & no & yes \\
\hline Calthropella & Astrophorida & Calthropellidae & $\begin{array}{l}\text { Tetractinellida } \\
\text { (Astrophorina) }\end{array}$ & Calthropellidae & no & yes \\
\hline Caminella & Astrophorida & Geodiidae & $\begin{array}{l}\text { Tetractinellida } \\
\text { (Astrophorina) }\end{array}$ & Geodiidae & no & yes \\
\hline Caminus & Astrophorida & Geodiidae & $\begin{array}{l}\text { Tetractinellida } \\
\text { (Astrophorina) }\end{array}$ & Geodiidae & $\mathrm{COI}$ & no \\
\hline Cantabrina & Poecilosclerida & Echinodictyinae & Poecilosclerida & Echinodictyinae & no & no \\
\hline Caulospongia & Hadromerida & Suberitidae & Suberitida & Suberitidae & no & yes \\
\hline Celtodoryx & Poecilosclerida & Coelosphaeridae & Poecilosclerida & Coelosphaeridae & no (contaminant) & no \\
\hline Ceratoporella & Agelasida & Astroscleridae & Agelasida & Astroscleridae & COI, ITS1-5.8S & no \\
\hline Ceratopsion & Poecilosclerida & Raspailiidae & Axinellida & Raspailiidae & no & yes \\
\hline Cerbaris & Halichondrida & Bubaridae & Bubarida & Bubaridae & no & no \\
\hline Cercicladia & Poecilosclerida & Cladorhizidae & Poecilosclerida & Cladorhizidae & no & no \\
\hline Cervicornia & Hadromerida & Clionaidae & Clionaida & Clionaidae & 185,285 & no \\
\hline Chaetodoryx & Poecilosclerida & Coelosphaeridae & Poecilosclerida & Coelosphaeridae & no & no \\
\hline Characella & Astrophorida & Pachastrellidae & $\begin{array}{l}\text { Tetractinellida } \\
\text { (Astrophorina) }\end{array}$ & $\begin{array}{l}\text { (Astrophorina) } \\
\text { incertae sedis }\end{array}$ & no & yes \\
\hline Chelotropella & Astrophorida & Ancorinidae & $\begin{array}{l}\text { Tetractinellida } \\
\text { (Astrophorina) }\end{array}$ & Ancorinidae & no & no \\
\hline
\end{tabular}


Table 1 Listing of Heteroscleromorpha genera in alphabetical order (Continued)

\begin{tabular}{|c|c|c|c|c|c|c|}
\hline Chondrocladia & Poecilosclerida & Cladorhizidae & Poecilosclerida & Cladorhizidae & no & yes \\
\hline Chondropsis & Poecilosclerida & Chondropsidae & Poecilosclerida & Chondropsidae & no & yes \\
\hline Cinachyra & Spirophorida & Tetillidae & $\begin{array}{l}\text { Tetractinellida } \\
\text { (Spirophorina) }\end{array}$ & Tetillidae & COI, 28S, $18 \mathrm{~S}$ & yes \\
\hline Cinachyrella & Spirophorida & Tetillidae & $\begin{array}{l}\text { Tetractinellida } \\
\text { (Spirophorina) }\end{array}$ & Tetillidae & no & yes \\
\hline Ciocalapata & Halichondrida & Halichondriidae & Suberitida & Halichondriidae & no & no \\
\hline Ciocalypta & Halichondrida & Halichondriidae & Suberitida & Halichondriidae & $18 \mathrm{~S}, 28 \mathrm{~S}, \mathrm{COI}$ & yes \\
\hline Cladorhiza & Poecilosclerida & Cladorhizidae & Poecilosclerida & Cladorhizidae & no & yes \\
\hline Cladothenea & Astrophorida & Theneidae & $\begin{array}{l}\text { Tetractinellida } \\
\text { (Astrophorina) }\end{array}$ & Theneidae & no & no \\
\hline Clathria & Poecilosclerida & Microcioninae & Poecilosclerida & Microcionidae & no & yes \\
\hline Cliona & Hadromerida & Clionaidae & Clionaida & Clionaidae & $18 \mathrm{~S}, 28 \mathrm{~S}, \mathrm{COI}$ & yes \\
\hline Clionaopsis & Hadromerida & Clionaidae & Clionaida & Clionaidae & no & no \\
\hline Cliothosa & Hadromerida & Clionaidae & Clionaida & Clionaidae & no & no \\
\hline Coelocarteria & Poecilosclerida & Isodictyidae & Poecilosclerida & Isodictyidae & 285 & no \\
\hline Coelodischela & Poecilosclerida & Guitarridae & Poecilosclerida & Guitarridae & no & no \\
\hline Coelosphaera & Poecilosclerida & Coelosphaeridae & Poecilosclerida & Coelosphaeridae & no & no \\
\hline Collectella & 'Lithistida' & $\begin{array}{l}\text { Lithistida incertae } \\
\text { sedis }\end{array}$ & $\begin{array}{l}\text { Tetractinellida } \\
\text { (Astrophorina) }\end{array}$ & Theonellidae & no & no \\
\hline Columnitis & Hadromerida & Tethyidae & Tethyida & Tethyidae & no & no \\
\hline Corallistes & 'Lithistida' & Corallistidae & $\begin{array}{l}\text { Tetractinellida } \\
\text { (Astrophorina) }\end{array}$ & Corallistidae & no & yes \\
\hline Cornulella & Poecilosclerida & Acarnidae & Poecilosclerida & Acarnidae & no & yes \\
\hline Cornulum & Poecilosclerida & Acarnidae & Poecilosclerida & Acarnidae & no & no \\
\hline Cortispongilla & Haplosclerida & Malawispongiidae & Spongillida & Malawispongiidae & COI, 18S, 5.8S-ITS2-28S & no \\
\hline Corvoheteromeyenia & Haplosclerida & Spongillidae & Spongillida & Spongillidae & no & no \\
\hline Corvomeyenia & Haplosclerida & Metaniidae & Spongillida & Metaniidae & no & yes \\
\hline Corvospongilla & Haplosclerida & Spongillidae & Spongillida & Spongillidae & no & no \\
\hline Costifer & 'Lithistida' & Isoraphiniidae & $\begin{array}{l}\text { Tetractinellida } \\
\text { (Astrophorina) }\end{array}$ & Isoraphiniidae & no & no \\
\hline Crambe & Poecilosclerida & Crambeidae & Poecilosclerida & Crambeidae & $18 \mathrm{~S}, 28 \mathrm{~S}$ & yes \\
\hline Craniella & Spirophorida & Tetillidae & $\begin{array}{l}\text { Tetractinellida } \\
\text { (Spirophorina) }\end{array}$ & Tetillidae & no & yes \\
\hline Crella & Poecilosclerida & Crellidae & Poecilosclerida & Crellidae & 18S, 28S, tpm & yes \\
\hline Crellastrina & Poecilosclerida & Crellidae & Poecilosclerida & Crellidae & no & no \\
\hline Crellomima & Poecilosclerida & Crellidae & Poecilosclerida & Crellidae & no & no \\
\hline Cryptax & Halichondrida & Halichondriidae & Suberitida & Halichondriidae & no & no \\
\hline Cryptosyringa & Astrophorida & Ancorinidae & $\begin{array}{l}\text { Tetractinellida } \\
\text { (Astrophorina) }\end{array}$ & Ancorinidae & no & no \\
\hline Cyamon & Poecilosclerida & Raspailiidae & Axinellida & Raspailiidae & no & no \\
\hline Cyclacanthia & Poecilosclerida & Latrunculiidae & Poecilosclerida & Latrunculiidae & no & no \\
\hline Cymbastela & Halichondrida & Axinellidae & Bubarida & Dictyonellidae & 285 & yes \\
\hline Daedalopelta & 'Lithistida' & Neopeltidae & $\begin{array}{l}\text { Tetractinellida } \\
\text { (Astrophorina) }\end{array}$ & Neopeltidae & no & no \\
\hline Damiria & Poecilosclerida & Acarnidae & Poecilosclerida & Acarnidae & no & no \\
\hline Damiriopsis & Poecilosclerida & Myxillidae & Poecilosclerida & Myxillidae & no & no \\
\hline
\end{tabular}


Table 1 Listing of Heteroscleromorpha genera in alphabetical order (Continued)

\begin{tabular}{|c|c|c|c|c|c|c|}
\hline Delectona & Astrophorida & Thoosidae & $\begin{array}{l}\text { Tetractinellida } \\
\text { (Astrophorina) }\end{array}$ & Thoosidae & no & no \\
\hline Dendoricella & Poecilosclerida & Dendoricellidae & Poecilosclerida & Dendoricellidae & no & no \\
\hline Dercitus & Astrophorida & Ancorinidae & $\begin{array}{l}\text { Tetractinellida } \\
\text { (Astrophorina) }\end{array}$ & Ancorinidae & $\mathrm{COI}, 18 \mathrm{~S}$ & yes \\
\hline Desmacella & Poecilosclerida & Desmacellidae & Desmacellida & Desmacellidae & $18 \mathrm{~S}, 28 \mathrm{~S}$ & yes \\
\hline Desmacidon & Poecilosclerida & Desmacididae & Poecilosclerida & Desmacididae & no & no \\
\hline Desmanthus & 'Lithistida' & Desmanthidae & Bubarida & Bubaridae & $18 \mathrm{~S}, 28 \mathrm{~S}, \mathrm{COI}$ & no \\
\hline Desmapsamma & Poecilosclerida & Desmacididae & Poecilosclerida & Desmacididae & $16 \mathrm{~S}, 18 \mathrm{~S}, 28 \mathrm{~S}, \mathrm{COI}$ & no \\
\hline Desmascula & 'Lithistida' & Azoricidae & $\begin{array}{l}\text { Tetractinellida } \\
\text { (Spirophorina) }\end{array}$ & Azoricidae & no & no \\
\hline Desmoxya & Halichondrida & Heteroxyidae & Axinellida & Heteroxyidae & no & no \\
\hline Diacarnus & Poecilosclerida & Podospongiidae & Poecilosclerida & Podospongiidae ${ }^{3}$ & $18 \mathrm{~S}, 28 \mathrm{~S}, \mathrm{COI}$ & no \\
\hline Dictyonella & Halichondrida & Dictyonellidae & Bubarida & Dictyonellidae & $18 \mathrm{~S}, 28 \mathrm{~S}$ & yes \\
\hline Didiscus & Halichondrida & Heteroxyidae & Axinellida & Raspailiidae & no & yes \\
\hline Diplastrella & Hadromerida & Spirastrellidae & Clionaida & Spirastrellidae & no & yes \\
\hline Diplopodospongia & Poecilosclerida & Podospongiidae & Poecilosclerida & Podospongiidae & no & no \\
\hline Discodermia & 'Lithistida' & Theonellidae & $\begin{array}{l}\text { Tetractinellida } \\
\text { (Astrophorina) }\end{array}$ & Theonellidae & no & yes \\
\hline Discorhabdella & Poecilosclerida & Crambeidae & Poecilosclerida & Crambeidae & no & no \\
\hline Disyringa & Astrophorida & Ancorinidae & $\begin{array}{l}\text { Tetractinellida } \\
\text { (Astrophorina) }\end{array}$ & Ancorinidae & $18 \mathrm{~S}, 28 \mathrm{~S}$ & no \\
\hline Dolichacantha & Poecilosclerida & Acarnidae & Poecilosclerida & Acarnidae & no & no \\
\hline Dosilia & Haplosclerida & Spongillidae & Spongillida & Spongillidae & no & no \\
\hline Dotona & Hadromerida & Clionaidae & Clionaida & Clionaidae & no & no \\
\hline Dragmacidon & Halichondrida & Axinellidae & Axinellida & Axinellidae & no & yes \\
\hline Dragmatella & Poecilosclerida & Desmacellidae & Desmacellida & Desmacellidae & no & no \\
\hline Dragmaxia & Halichondrida & Axinellidae & Axinellida & Axinellidae & no & yes \\
\hline Drulia & Haplosclerida & Metaniidae & Spongillida & Metaniidae & 5.8S-ITS2-28S & no \\
\hline Duosclera & Haplosclerida & Spongillidae & Spongillida & Spongillidae & no & no \\
\hline Dyscliona & Hadromerida & Clionaidae & Clionaida & Clionaidae & no & no \\
\hline Echinochalina & Poecilosclerida & Microcioninae & Poecilosclerida & Microcionidae & no & yes \\
\hline Echinoclathria & Poecilosclerida & Ophlitaspongiinae & Poecilosclerida & Microcionidae & no & yes \\
\hline Echinodictyum & Poecilosclerida & Echinodictyinae & Poecilosclerida & Echinodictyinae & no & yes \\
\hline Echinospongilla & Haplosclerida & Potamolepidae & Spongillida & Potamolepidae & $\begin{array}{l}\text { COI, 18S, ITS1-5.8S-ITS2- } \\
28 \mathrm{~S}\end{array}$ & no \\
\hline Echinostylinos & Poecilosclerida & Phellodermidae & Poecilosclerida & Phellodermidae & no & no \\
\hline Ecionemia & Astrophorida & Ancorinidae & $\begin{array}{l}\text { Tetractinellida } \\
\text { (Astrophorina) }\end{array}$ & Ancorinidae & $18 \mathrm{~S}$ & yes \\
\hline Ectyonopsis & Poecilosclerida & Myxillidae & Poecilosclerida & Myxillidae & no & yes \\
\hline Ectyoplasia & Poecilosclerida & Raspailiidae & Axinellida & Raspailiidae & $18 \mathrm{~S}, 28 \mathrm{~S}$ & yes \\
\hline Endectyon & Poecilosclerida & Raspailiidae & Axinellida & Raspailiidae & no & yes \\
\hline Eospongilla & Haplosclerida & Palaeospongillidae & Spongillida & Palaeospongillidae & no & no \\
\hline Ephydatia & Haplosclerida & Spongillidae & Spongillida & Spongillidae & $\begin{array}{l}\text { COI, 18S, 5.8S-ITS2-28S, } \\
\text { mt, ESTs }\end{array}$ & yes \\
\hline Epipolasis & Halichondrida & Axinellidae & Axinellida & Axinellidae & no & yes \\
\hline Erylus & Astrophorida & Geodiidae & $\begin{array}{l}\text { Tetractinellida } \\
\text { (Astrophorina) }\end{array}$ & Geodiidae & $\mathrm{COI}, 28 \mathrm{~S}$ & yes \\
\hline
\end{tabular}


Table 1 Listing of Heteroscleromorpha genera in alphabetical order (Continued)

\begin{tabular}{|c|c|c|c|c|c|c|}
\hline Esperiopsis & Poecilosclerida & Esperiopsidae & Poecilosclerida & Esperiopsidae & no & no \\
\hline Euchelipluma & Poecilosclerida & Guitarridae & Poecilosclerida & Guitarridae & no & no \\
\hline Eunapius & Haplosclerida & Spongillidae & Spongillida & Spongillidae & COI, ITS2, $18 \mathrm{~S}$ & yes \\
\hline Eurypon & Poecilosclerida & Raspailiidae & Axinellida & Raspailiidae & no & yes \\
\hline Exsuperantia & 'Lithistida' & Phymaraphiniidae & $\begin{array}{l}\text { Tetractinellida } \\
\text { (Astrophorina) }\end{array}$ & Phymaraphiniidae & no & yes \\
\hline Fangophilina & Spirophorida & Tetillidae & $\begin{array}{l}\text { Tetractinellida } \\
\text { (Spirophorina) }\end{array}$ & Tetillidae & no & yes \\
\hline Fibulia & Poecilosclerida & Dendoricellidae & Poecilosclerida & Dendoricellidae & no & no \\
\hline Forcepia & Poecilosclerida & Coelosphaeridae & Poecilosclerida & Coelosphaeridae & no & yes \\
\hline Gastrophanella & 'Lithistida' & Siphonidiidae & $\begin{array}{l}\text { Tetractinellida } \\
\text { (Spirophorina) }\end{array}$ & Siphonidiidae & no & no \\
\hline Geodia & Astrophorida & Geodiidae & $\begin{array}{l}\text { Tetractinellida } \\
\text { (Astrophorina) }\end{array}$ & Geodiidae & no & yes \\
\hline Goreauiella & Agelasida & Astroscleridae & Agelasida & Astroscleridae & no & no \\
\hline Guitarra & Poecilosclerida & Guitarridae & Poecilosclerida & Guitarridae & $28 \mathrm{~S}$ & no \\
\hline Halichondria & Halichondrida & Halichondriidae & Suberitida & Halichondriidae & $18 \mathrm{~S}, 28 \mathrm{~S}, 5.8 \mathrm{~S}, \mathrm{COI}$ & yes \\
\hline Halicnemia & Halichondrida & Heteroxyidae & Axinellida & Stelligeridae & no & yes \\
\hline Halicometes & Hadromerida & Tethyidae & Tethyida & Tethyidae & no & no \\
\hline Hamacantha & Poecilosclerida & Hamacanthidae & Merliida & Hamacanthidae & no & no \\
\hline Hamigera & Poecilosclerida & Hymedesmiidae & Poecilosclerida & Hymedesmiidae & $18 \mathrm{~S}, 28 \mathrm{~S}$ & yes \\
\hline Hemiasterella & Hadromerida & Hemiasterellidae & Tethyida & Hemiasterellidae & no & yes \\
\hline Hemimycale & Poecilosclerida & Hymedesmiidae & Poecilosclerida & Hymedesmiidae & $18 \mathrm{~S}, 28 \mathrm{~S}$ & no \\
\hline Hemitedania & Poecilosclerida & Tedaniidae & Poecilosclerida & Tedaniidae & no & no \\
\hline Herengeria & 'Lithistida' & Corallistidae & $\begin{array}{l}\text { Tetractinellida } \\
\text { (Astrophorina) }\end{array}$ & Corallistidae & no & no \\
\hline Heteromeyenia & Haplosclerida & Spongillidae & Spongillida & Spongillidae & no & no \\
\hline Heterorotula & Haplosclerida & Spongillidae & Spongillida & Spongillidae & no & yes \\
\hline Heteroxya & Halichondrida & Heteroxyidae & Axinellida & Heteroxyidae & no & no \\
\hline Higginsia & Halichondrida & Heteroxyidae & Axinellida & Stelligeridae & no & yes \\
\hline Hispidopetra & Agelasida & Astroscleridae & Agelasida & Astroscleridae & no & no \\
\hline Histodermella & Poecilosclerida & Coelosphaeridae & Poecilosclerida & Coelosphaeridae & no & no \\
\hline Holopsamma & Poecilosclerida & Microcioninae & Poecilosclerida & Microcionidae & no & yes \\
\hline Holoxea & Astrophorida & Ancorinidae & $\begin{array}{l}\text { Tetractinellida } \\
\text { (Astrophorina) }\end{array}$ & Ancorinidae & no & yes \\
\hline Homaxinella & Hadromerida & Suberitidae & Suberitida & $\begin{array}{l}\text { Suberitida incertae } \\
\text { sedis }\end{array}$ & no & yes \\
\hline Homophymia & 'Lithistida' & Neopeltidae & $\begin{array}{l}\text { Tetractinellida } \\
\text { (Astrophorina) }\end{array}$ & Neopeltidae & no & yes \\
\hline Houssayella & Haplosclerida & Metaniidae & Spongillida & Metaniidae & no & no \\
\hline Hymedesmia & Poecilosclerida & Hymedesmiidae & Poecilosclerida & Hymedesmiidae & no & yes \\
\hline Hymenancora & Poecilosclerida & Myxillidae & Poecilosclerida & Myxillidae & no & no \\
\hline Hymeniacidon & Halichondrida & Halichondriidae & Suberitida & Halichondriidae & $18 \mathrm{~S}, 28 \mathrm{~S}, \mathrm{COI}$ & yes \\
\hline Hymeraphia & Poecilosclerida & Raspailiidae & Axinellida & Raspailiidae & $18 \mathrm{~S}, 28 \mathrm{~S}$ & yes \\
\hline Hymerhabdia & Agelasida & Hymerhabdiidae & Agelasida & Hymerhabdiidae & $18 \mathrm{~S}, 28 \mathrm{~S}, \mathrm{COI}$ & no \\
\hline Hymetrochota & Poecilosclerida & lotrochotidae & Poecilosclerida & lotrochotidae & no & no \\
\hline Inflatella & Poecilosclerida & Coelosphaeridae & Poecilosclerida & Coelosphaeridae & $18 \mathrm{~S}$ & no \\
\hline lophon & Poecilosclerida & Acarnidae & Poecilosclerida & Acarnidae & no & yes \\
\hline
\end{tabular}


Table 1 Listing of Heteroscleromorpha genera in alphabetical order (Continued)

\begin{tabular}{|c|c|c|c|c|c|c|}
\hline lotroata & Poecilosclerida & lotrochotidae & Poecilosclerida & lotrochotidae & no & no \\
\hline lotrochopsamma & Poecilosclerida & lotrochotidae & Poecilosclerida & lotrochotidae & no & no \\
\hline lotrochota & Poecilosclerida & lotrochotidae & Poecilosclerida & lotrochotidae & $18 \mathrm{~S}, 28 \mathrm{~S}, \mathrm{mt}$ & no \\
\hline Isabella & 'Lithistida' & Corallistidae & $\begin{array}{l}\text { Tetractinellida } \\
\text { (Astrophorina) }\end{array}$ & Corallistidae & no & no \\
\hline Isodictya & Poecilosclerida & Isodictyidae & Poecilosclerida & Isodictyidae & no & yes \\
\hline Janulum & Poecilosclerida & Raspailiidae & Haplosclerida & Phloeodictyidae & $18 \mathrm{~S}$ & no \\
\hline Jaspis & Astrophorida & Ancorinidae & $\begin{array}{l}\text { Tetractinellida } \\
\text { (Astrophorina) }\end{array}$ & Ancorinidae & no & yes \\
\hline Jereicopsis & 'Lithistida' & Azoricidae & $\begin{array}{l}\text { Tetractinellida } \\
\text { (Spirophorina) }\end{array}$ & Azoricidae & no & no \\
\hline Johannesia & Halichondrida & Halichondriidae & Suberitida & Halichondriidae & no & no \\
\hline Julavis & Halichondrida & Heteroxyidae & Axinellida & Heteroxyidae & no & no \\
\hline Kaliapsis & 'Lithistida' & Phymaraphiniidae & $\begin{array}{l}\text { Tetractinellida } \\
\text { (Astrophorina) }\end{array}$ & Phymaraphiniidae & no & no \\
\hline Kirkpatrickia & Poecilosclerida & Hymedesmiidae & Poecilosclerida & Hymedesmiidae & no & no \\
\hline Lamellomorpha & Astrophorida & Pachastrellidae & $\begin{array}{l}\text { Tetractinellida } \\
\text { (Astrophorina) }\end{array}$ & $\begin{array}{l}\text { (Astrophorina) } \\
\text { incertae sedis }\end{array}$ & 185 & no \\
\hline Laminospongia & Halichondrida & Halichondriidae & Suberitida & Halichondriidae & no & no \\
\hline Latrunculia & Poecilosclerida & Latrunculiidae & Poecilosclerida & Latrunculiidae & no & yes \\
\hline Laxotethya & Hadromerida & Tethyidae & Tethyida & Tethyidae & 285 & no \\
\hline Leiodermatium & 'Lithistida' & Azoricidae & $\begin{array}{l}\text { Tetractinellida } \\
\text { (Spirophorina) }\end{array}$ & Azoricidae & no & no \\
\hline Lepidosphaera & Poecilosclerida & Coelosphaeridae & Poecilosclerida & Coelosphaeridae & no & no \\
\hline Lepidothenea & 'Lithistida' & Phymaraphiniidae & $\begin{array}{l}\text { Tetractinellida } \\
\text { (Astrophorina) }\end{array}$ & Phymaraphiniidae & no & no \\
\hline Leptosastra & Hadromerida & Hemiasterellidae & Tethyida & Hemiasterellidae & no & no \\
\hline Liosina & Halichondrida & Dictyonellidae & Tethyida & Hemiasterellidae & $28 \mathrm{~S}, \mathrm{COI}$ & no \\
\hline Lipastrotethya & Halichondrida & Dictyonellidae & Bubarida & Dictyonellidae & no & no \\
\hline Lissodendoryx & Poecilosclerida & Coelosphaeridae & Poecilosclerida & Coelosphaeridae & no & yes \\
\hline Lithobactrum & 'Lithistida' & Siphonidiidae & $\begin{array}{l}\text { Tetractinellida } \\
\text { (Spirophorina) }\end{array}$ & Siphonidiidae & no & no \\
\hline Lithochela & Poecilosclerida & Crambeidae & Poecilosclerida & Crambeidae & no & no \\
\hline Lithoplocamia & Poecilosclerida & Raspailiidae & Poecilosclerida & Raspailiidae & no & no \\
\hline Lollipocladia & Poecilosclerida & Cladorhizidae & Poecilosclerida & Cladorhizidae & no & no \\
\hline Lubomirskia & Haplosclerida & Lubomirskiidae & Spongillida & Lubomirskiidae & 65 sequences, mt, ESTs & yes \\
\hline Lutetiospongilla & Haplosclerida & Palaeospongillidae & Spongillida & Palaeospongillidae & no & no \\
\hline Macandrewia & 'Lithistida' & Macandrewiidae & $\begin{array}{l}\text { Tetractinellida } \\
\text { (Astrophorina) }\end{array}$ & Macandrewiidae & no & no \\
\hline Makedia & Haplosclerida & $\begin{array}{l}\text { Spongillina incertae } \\
\text { sedis }\end{array}$ & Spongillida & $\begin{array}{l}\text { Spongillida incertae } \\
\text { sedis }\end{array}$ & no & no \\
\hline Malawispongia & Haplosclerida & Malawispongiidae & Spongillida & Malawispongiidae & no & no \\
\hline Manihinea & 'Lithistida' & Theonellidae & $\begin{array}{l}\text { Tetractinellida } \\
\text { (Astrophorina) }\end{array}$ & Theonellidae & 185 & no \\
\hline Megaciella & Poecilosclerida & Acarnidae & Poecilosclerida & Acarnidae & no & no \\
\hline Melonanchora & Poecilosclerida & Myxillidae & Poecilosclerida & Myxillidae & no & no \\
\hline Melophlus & Astrophorida & Geodiidae & $\begin{array}{l}\text { Tetractinellida } \\
\text { (Astrophorina) }\end{array}$ & Geodiidae & no & yes \\
\hline Merlia & Poecilosclerida & Merliidae & Merliida & Merliidae & $16 \mathrm{~S}, 18 \mathrm{~S}, 28 \mathrm{~S}$ & no \\
\hline
\end{tabular}


Table 1 Listing of Heteroscleromorpha genera in alphabetical order (Continued)

\begin{tabular}{|c|c|c|c|c|c|c|}
\hline Metania & Haplosclerida & Metaniidae & Spongillida & Metaniidae & no & no \\
\hline Metschnikowia & Haplosclerida & Metschnikowiidae & Spongillida & Metschnikowiidae & no & no \\
\hline Microscleroderma & 'Lithistida' & Scleritodermidae & $\begin{array}{l}\text { Tetractinellida } \\
\text { (Spirophorina) }\end{array}$ & Scleritodermidae & no & yes \\
\hline Microtylostylifer & Poecilosclerida & Desmacellidae & Desmacellida & Desmacellidae & no & no \\
\hline Microxistyla & Halichondrida & Heteroxyidae & Axinellida & Heteroxyidae & no & no \\
\hline Monanchora & Poecilosclerida & Crambeidae & Poecilosclerida & Crambeidae & 28S, COI & yes \\
\hline Monocrepidium & Halichondrida & Bubaridae & Bubarida & Bubaridae & no & no \\
\hline Mycale & Poecilosclerida & Mycalidae & Poecilosclerida & Mycalidae & no & yes \\
\hline Myrmekioderma & Halichondrida & Heteroxyidae & Axinellida & Heteroxyidae & 18S, 28S, COI & yes \\
\hline Myxilla & Poecilosclerida & Myxillidae & Poecilosclerida & Myxillidae & 285 & yes \\
\hline Myxodoryx & Poecilosclerida & Hymedesmiidae & Poecilosclerida & Hymedesmiidae & no & no \\
\hline Neamphius & Astrophorida & Thoosidae & $\begin{array}{l}\text { Tetractinellida } \\
\text { (Astrophorina) }\end{array}$ & $\begin{array}{l}\text { (Astrophorina) } \\
\text { incertae sedis }\end{array}$ & $\mathrm{COI}, 28 \mathrm{~S}$ & yes \\
\hline Negombata & Poecilosclerida & Podospongiidae & Poecilosclerida & Podospongiidae & 18S, COI & yes \\
\hline Negombo & Halichondrida & Heteroxyidae & Axinellida & Heteroxyidae & no & no \\
\hline Neoaulaxinia & 'Lithistida' & Phymatellidae & $\begin{array}{l}\text { Tetractinellida } \\
\text { (Astrophorina) }\end{array}$ & Phymatellidae & no & no \\
\hline Neocladia & Poecilosclerida & Cladorhizidae & Poecilosclerida & Cladorhizidae & no & yes \\
\hline Neofibularia & Poecilosclerida & Desmacellidae & Biemnida & Biemnidae & 18S, 28S, COI & yes \\
\hline Neopelta & 'Lithistida' & Neopeltidae & $\begin{array}{l}\text { Tetractinellida } \\
\text { (Astrophorina) }\end{array}$ & Neopeltidae & no & no \\
\hline Neophrissospongia & 'Lithistida' & Corallistidae & $\begin{array}{l}\text { Tetractinellida } \\
\text { (Astrophorina) }\end{array}$ & Corallistidae & no & yes \\
\hline Neopodospongia & Poecilosclerida & Podospongiidae & Poecilosclerida & Podospongiidae & no & yes \\
\hline Neoschrammeniella & 'Lithistida' & Corallistidae & $\begin{array}{l}\text { Tetractinellida } \\
\text { (Astrophorina) }\end{array}$ & Corallistidae & no & no \\
\hline Neosiphonia & 'Lithistida' & Phymatellidae & $\begin{array}{l}\text { Tetractinellida } \\
\text { (Astrophorina) }\end{array}$ & Phymatellidae & no & no \\
\hline Nethea & Astrophorida & Pachastrellidae & $\begin{array}{l}\text { Tetractinellida } \\
\text { (Astrophorina) }\end{array}$ & Pachastrellidae & no & yes \\
\hline Nucleotethya & Hadromerida & Tethyidae & Tethyida & Tethyidae & no & no \\
\hline Nudospongilla & Haplosclerida & Spongillidae & Spongillida & Spongillidae & no & yes \\
\hline Ochridaspongia & Haplosclerida & Malawispongiidae & Spongillida & Malawispongiidae & no & no \\
\hline Ohridospongilla & Haplosclerida & $\begin{array}{l}\text { Spongillina incertae } \\
\text { sedis }\end{array}$ & Spongillida & $\begin{array}{l}\text { Spongillida incertae } \\
\text { sedis }\end{array}$ & no & yes \\
\hline Oncosclera & Haplosclerida & Potamolepidae & Spongillida & Potamolepidae & no & yes \\
\hline Onotoa & Hadromerida & Placospongiidae & Clionaida & Placospongiidae & no & no \\
\hline Ophiraphidites & Halichondrida & Axinellidae & Bubarida & Bubaridae & no & no \\
\hline Ophlitaspongia & Poecilosclerida & Ophlitaspongiinae & Poecilosclerida & Microcionidae & $16 S, 18 S$ & no \\
\hline Oxytethya & Hadromerida & Tethyidae & Tethyida & Tethyidae & no & no \\
\hline Pachastrella & Astrophorida & Pachastrellidae & $\begin{array}{l}\text { Tetractinellida } \\
\text { (Astrophorina) }\end{array}$ & Pachastrellidae & no & yes \\
\hline Pachydictyum & Haplosclerida & Malawispongiidae & Spongillida & Malawispongiidae & COI, 18S, ESTs & yes \\
\hline Pachymatisma & Astrophorida & Geodiidae & $\begin{array}{l}\text { Tetractinellida } \\
\text { (Astrophorina) }\end{array}$ & Geodiidae & $\begin{array}{l}\text { COI, 28S, 18S, ITS1-5.8S- } \\
\text { ITS2 }\end{array}$ & yes \\
\hline Pachyrotula & Haplosclerida & Spongillidae & Spongillida & Spongillidae & no & no \\
\hline Palaeospongilla & Haplosclerida & Palaeospongillidae & Spongillida & Palaeospongillidae & no & no \\
\hline Pandaros & Poecilosclerida & Raspailiidae & Axinellida & Raspailiidae & $\mathrm{COI}$ & no \\
\hline
\end{tabular}


Table 1 Listing of Heteroscleromorpha genera in alphabetical order (Continued)

\begin{tabular}{|c|c|c|c|c|c|c|}
\hline Paracornulum & Poecilosclerida & Acarnidae & Poecilosclerida & Acarnidae & $\mathrm{COI}$ & no \\
\hline Paradesmanthus & 'Lithistida' & Desmanthidae & Bubarida & Bubaridae & no & no \\
\hline Parahigginsia & Halichondrida & Heteroxyidae & Axinellida & Heteroxyidae & no & no \\
\hline Pararhaphoxya & Halichondrida & Axinellidae & Bubarida & Bubaridae & no & yes \\
\hline Paratetilla & Spirophorida & Tetillidae & $\begin{array}{l}\text { Tetractinellida } \\
\text { (Spirophorina) }\end{array}$ & Tetillidae & no & yes \\
\hline Paratimea & Hadromerida & Stelligeridae & Axinellida & Stelligeridae & no & yes \\
\hline Pectispongilla & Haplosclerida & Spongillidae & Spongillida & Spongillidae & no & no \\
\hline Penares & Astrophorida & Geodiidae & $\begin{array}{l}\text { Tetractinellida } \\
\text { (Astrophorina) }\end{array}$ & Geodiidae & 5.8S-ITS2-28S & yes \\
\hline Penicillus & Hadromerida & Polymastiidae & Polymastiida & Polymastiidae & no & no \\
\hline Petromica & 'Lithistida' & Desmanthidae & incertae sedis & & no & yes \\
\hline Phakellia & Halichondrida & Axinellidae & Bubarida & Bubaridae & $18 \mathrm{~S}, 28 \mathrm{~S}, \mathrm{COI}$ & yes \\
\hline Phakettia & Halichondrida & Dictyonellidae & Bubarida & Dictyonellidae & no & yes \\
\hline Phelloderma & Poecilosclerida & Phellodermidae & Poecilosclerida & Phellodermidae & no & yes \\
\hline Phlyctaenopora & Poecilosclerida & Mycalidae & Poecilosclerida & Mycalidae & no & no \\
\hline Phorbas & Poecilosclerida & Hymedesmiidae & Poecilosclerida & Hymedesmiidae & $18 \mathrm{~S}$ & yes \\
\hline Phoriospongia & Poecilosclerida & Chondropsidae & Poecilosclerida & Chondropsidae & no & no \\
\hline Phycopsis & Halichondrida & Axinellidae & Bubarida & Bubaridae & no & yes \\
\hline Pione & Hadromerida & Clionaidae & Clionaida & Clionaidae & no & yes \\
\hline Pipestela & Halichondrida & Axinellidae & Bubarida & Bubaridae & no & no \\
\hline Placospherastra & Hadromerida & Placospongiidae & Clionaida & Placospongiidae & no & no \\
\hline Placospongia & Hadromerida & Placospongiidae & Clionaida & Placospongiidae & $18 \mathrm{~S}, \mathrm{COI}$ & yes \\
\hline Plakidium & 'Lithistida' & $\begin{array}{l}\text { Lithistida incertae } \\
\text { sedis }\end{array}$ & incertae sedis & & no & no \\
\hline Pleroma & 'Lithistida' & Pleromidae & $\begin{array}{l}\text { Tetractinellida } \\
\text { (Astrophorina) }\end{array}$ & Pleromidae & no & no \\
\hline Plicatellopsis & Hadromerida & Suberitidae & Suberitida & Suberitidae & no & no \\
\hline Plocamiancora & Poecilosclerida & Myxillidae & Poecilosclerida & Myxillidae & no & yes \\
\hline Plocamione & Poecilosclerida & Raspailiidae & Poecilosclerida & Raspailiidae & no & no \\
\hline Plocamionida & Poecilosclerida & Hymedesmiidae & Poecilosclerida & Hymedesmiidae & $18 \mathrm{~S}, 28 \mathrm{~S}, \mathrm{COI}$ & yes \\
\hline Podospongia & Poecilosclerida & Podospongiidae & Poecilosclerida & Podospongiidae & no & no \\
\hline Poecillastra & Astrophorida & Vulcanellidae & $\begin{array}{l}\text { Tetractinellida } \\
\text { (Astrophorina) }\end{array}$ & Vulcanellidae & $\mathrm{COI}, 28 \mathrm{~S}$ & yes \\
\hline Polymastia & Hadromerida & Polymastiidae & Polymastiida & Polymastiidae & no & yes \\
\hline Pomelia & 'Lithistida' & Scleritodermidae & $\begin{array}{l}\text { Tetractinellida } \\
\text { (Spirophorina) }\end{array}$ & Scleritodermidae & no & no \\
\hline Poritella & 'Lithistida' & $\begin{array}{l}\text { Lithistida incertae } \\
\text { sedis }\end{array}$ & incertae sedis & & no & no \\
\hline Potamolepis & Haplosclerida & Potamolepidae & Spongillida & Potamolepidae & no & yes \\
\hline Potamophloios & Haplosclerida & Potamolepidae & Spongillida & Potamolepidae & no & no \\
\hline Pottsiela & Haplosclerida & Spongillidae & Spongillida & Spongillidae & no & no \\
\hline Pozziella & Poecilosclerida & Hamacanthidae & Merliida & Hamacanthidae & no & no \\
\hline Prosuberites & Hadromerida & Suberitidae & Agelasida & Hymerhabdiidae & 285 & yes \\
\hline Proteleia & Hadromerida & Polymastiidae & Polymastiida & Polymastiidae & 185 & no \\
\hline Protosuberites & Hadromerida & Suberitidae & Suberitida & Suberitidae & no & yes \\
\hline Psammastra & Astrophorida & Ancorinidae & $\begin{array}{l}\text { Tetractinellida } \\
\text { (Astrophorina) }\end{array}$ & Ancorinidae & no & no \\
\hline
\end{tabular}


Table 1 Listing of Heteroscleromorpha genera in alphabetical order (Continued)

\begin{tabular}{|c|c|c|c|c|c|c|}
\hline Psammochela & Poecilosclerida & Myxillidae & Poecilosclerida & Myxillidae & no & no \\
\hline Psammoclema & Poecilosclerida & Chondropsidae & Poecilosclerida & Chondropsidae & no & yes \\
\hline Pseudohalichondria & Poecilosclerida & Hymedesmiidae & Poecilosclerida & Hymedesmiidae & no & no \\
\hline Pseudospongosorites & Hadromerida & Suberitidae & Suberitida & Suberitidae & tpm & no \\
\hline Pseudosuberites & Hadromerida & Suberitidae & Suberitida & Suberitidae & no & yes \\
\hline Pseudotrachya & Hadromerida & Polymastiidae & Polymastiida & Polymastiidae & no & no \\
\hline Ptilocaulis & Halichondrida & Axinellidae & Axinellida & Raspailiidae & $18 \mathrm{~S}, 28 \mathrm{~S}, \mathrm{mt}$ & yes \\
\hline Pyloderma & Poecilosclerida & Dendoricellidae & Poecilosclerida & Dendoricellidae & no & no \\
\hline Quasillina & Hadromerida & Polymastiidae & Polymastiida & Polymastiidae & 185 & no \\
\hline Racekiela & Haplosclerida & Spongillidae & Spongillida & Spongillidae & no & no \\
\hline Racodiscula & 'Lithistida' & Theonellidae & $\begin{array}{l}\text { Tetractinellida } \\
\text { (Astrophorina) }\end{array}$ & Theonellidae & no & no \\
\hline Radiella & Hadromerida & Polymastiidae & Polymastiida & Polymastiidae & no & no \\
\hline Radiospongilla & Haplosclerida & Spongillidae & Spongillida & Spongillidae & no & yes \\
\hline Raspaciona & Poecilosclerida & Raspailiidae & Axinellida & Raspailiidae & $18 \mathrm{~S}, 28 \mathrm{~S}, \mathrm{COI}$ & no \\
\hline Raspailia & Poecilosclerida & Raspailiidae & Axinellida & Raspailiidae & no & yes \\
\hline Reidispongia & 'Lithistida' & Phymatellidae & $\begin{array}{l}\text { Tetractinellida } \\
\text { (Astrophorina) }\end{array}$ & Phymatellidae & no & no \\
\hline Reniochalina & Halichondrida & Axinellidae & Axinellida & Raspailiidae & $18 \mathrm{~S}, 28 \mathrm{~S}$ & yes \\
\hline Rezinkovia & Haplosclerida & Lubomirskiidae & Spongillida & Lubomirskiidae & 18S-5.8S-ITS2-28S, mt & yes \\
\hline Rhabdastrella & Astrophorida & Ancorinidae & $\begin{array}{l}\text { Tetractinellida } \\
\text { (Astrophorina) }\end{array}$ & Geodiidae & no & yes \\
\hline Rhabderemia & Poecilosclerida & Rhabderemiidae & Biemnida & Rhabderemiidae & no & yes \\
\hline Rhabdeurypon & Poecilosclerida & Raspailiidae & Axinellida & Raspailiidae & no & no \\
\hline Rhabdobaris & Halichondrida & Bubaridae & Bubarida & Bubaridae & no & no \\
\hline Rhaphidhistia & Hadromerida & Trachycladidae & Trachycladida & Trachycladidae & no & no \\
\hline Rhaphoxya & Halichondrida & Dictyonellidae & Bubarida & Dictyonellidae & no & no \\
\hline Rhizaxinella & Hadromerida & Suberitidae & Suberitida & Suberitidae & no & yes \\
\hline Ridleia & Hadromerida & Polymastiidae & Polymastiida & Polymastiidae & no & no \\
\hline Rotuloplocamia & Poecilosclerida & lotrochotidae & Poecilosclerida & lotrochotidae & no & no \\
\hline Samus & Spirophorida & Samidae & $\begin{array}{l}\text { Tetractinellida } \\
\text { (Spirophorina) }\end{array}$ & Samidae & no & no \\
\hline Sanidastra & Haplosclerida & Spongillidae & Spongillida & Spongillidae & no & no \\
\hline Sarcomella & Halichondrida & Halichondriidae & Suberitida & Halichondriidae & no & no \\
\hline Saturnospongilla & Haplosclerida & Spongillidae & Spongillida & Spongillidae & no & no \\
\hline Sceptrella & Poecilosclerida & Latrunculiidae & Poecilosclerida & Latrunculiidae & no & yes \\
\hline Sceptrintus & Poecilosclerida & Podospongiidae & Poecilosclerida & Podospongiidae & no & no \\
\hline Scleritoderma & 'Lithistida' & Scleritodermidae & $\begin{array}{l}\text { Tetractinellida } \\
\text { (Spirophorina) }\end{array}$ & Scleritodermidae & no & no \\
\hline Scolopes & Hadromerida & Clionaidae & Clionaida & Clionaidae & no & no \\
\hline Scopalina & Halichondrida & Scopalinidae & Scopalinida & Scopalinidae & 18S, 28S, COI & yes \\
\hline Semisuberites & Poecilosclerida & Esperiopsidae & Poecilosclerida & Esperiopsidae & no & no \\
\hline Setidium & 'Lithistida' & Scleritodermidae & $\begin{array}{l}\text { Tetractinellida } \\
\text { (Spirophorina) }\end{array}$ & Scleritodermidae & no & no \\
\hline Sigmaxinella & Poecilosclerida & Desmacellidae & Biemnida & Biemnidae & no & yes \\
\hline Sigmeurypon & Poecilosclerida & Ophlitaspongiinae & Poecilosclerida & Microcionidae & no & no \\
\hline Sigmosceptrella & Poecilosclerida & Podospongiidae & Poecilosclerida & Podospongiidae & no & no \\
\hline
\end{tabular}


Table 1 Listing of Heteroscleromorpha genera in alphabetical order (Continued)

\begin{tabular}{|c|c|c|c|c|c|c|}
\hline Siliquariaspongia & 'Lithistida' & Theonellidae & $\begin{array}{l}\text { Tetractinellida } \\
\text { (Astrophorina) }\end{array}$ & Theonellidae & no & no \\
\hline Siphonidium & 'Lithistida' & Siphonidiidae & $\begin{array}{l}\text { Tetractinellida } \\
\text { (Spirophorina) }\end{array}$ & Siphonidiidae & no & no \\
\hline Sollasella & Poecilosclerida & Raspailiidae & Axinellida & Raspailiidae & no & yes \\
\hline Spanioplon & Poecilosclerida & Hymedesmiidae & Poecilosclerida & Hymedesmiidae & $18 \mathrm{~S}, 28 \mathrm{~S}$ & no \\
\hline Sphaerotylus & Hadromerida & Polymastiidae & Polymastiida & Polymastiidae & no & yes \\
\hline Spheciospongia & Hadromerida & Clionaidae & Clionaida & Clionaidae & 185 & yes \\
\hline Spinospongilla & Haplosclerida & Malawispongiidae & Spongillida & Malawispongiidae & no & no \\
\hline Spinularia & Hadromerida & Polymastiidae & Polymastiida & Polymastiidae & no & no \\
\hline Spirasigma & Spirophorida & Spirasigmidae & $\begin{array}{l}\text { Tetractinellida } \\
\text { (Spirophorina) }\end{array}$ & Spirasigmidae & no & no \\
\hline Spirastrella & Hadromerida & Spirastrellidae & Clionaida & Spirastrellidae & no & yes \\
\hline Spirorhabdia & Poecilosclerida & Crellidae & Poecilosclerida & Crellidae & no & no \\
\hline Spiroxya & Hadromerida & Clionaidae & Clionaida & Clionaidae & no & no \\
\hline Spongilla & Haplosclerida & Spongillidae & Spongillida & Spongillidae & $\begin{array}{l}\text { COI,18S, 28S, ITS1-5.8S- } \\
\text { ITS2-28S, tpm }\end{array}$ & yes \\
\hline Spongosorites & Halichondrida & Halichondriidae & Suberitida & Halichondriidae & no & yes \\
\hline Stelletta & Astrophorida & Ancorinidae & $\begin{array}{l}\text { Tetractinellida } \\
\text { (Astrophorina) }\end{array}$ & Ancorinidae & COI, 28S, $18 \mathrm{~S}$ & yes \\
\hline Stellettinopsis & Astrophorida & Ancorinidae & $\begin{array}{l}\text { Tetractinellida } \\
\text { (Astrophorina) }\end{array}$ & Ancorinidae & no & yes \\
\hline Stelligera & Hadromerida & Stelligeridae & Axinellida & Stelligeridae & 18S, 28S, COI & yes \\
\hline Stellitethya & Hadromerida & Tethyidae & Tethyida & Tethyidae & no & yes \\
\hline Stelodoryx & Poecilosclerida & Myxillidae & Poecilosclerida & Myxillidae & no & no \\
\hline Sterrastrolepis & Haplosclerida & Potamolepidae & Spongillida & Potamolepidae & no & no \\
\hline Stratospongilla & Haplosclerida & Spongillidae & Spongillida & Spongillidae & no & no \\
\hline Stromatospongia & Agelasida & Astroscleridae & Agelasida & Astroscleridae & no & no \\
\hline Strongylacidon & Poecilosclerida & Chondropsidae & Poecilosclerida & Chondropsidae & no & yes \\
\hline Strongylamma & Poecilosclerida & Tedaniidae & Poecilosclerida & Tedaniidae & no & no \\
\hline Strongylodesma & Poecilosclerida & Latrunculiidae & Poecilosclerida & Latrunculiidae & no & no \\
\hline Stryphnus & Astrophorida & Ancorinidae & $\begin{array}{l}\text { Tetractinellida } \\
\text { (Astrophorina) }\end{array}$ & Ancorinidae & no & yes \\
\hline Stylissa & Halichondrida & Scopalinidae & Scopalinida & Scopalinidae & $18 \mathrm{~S}, 28 \mathrm{~S}, \mathrm{COI}$ & yes \\
\hline Stylocordyla & Hadromerida & Stylocordylidae & Suberitida & Stylocordylidae & COI (submitted) & no \\
\hline Suberites & Hadromerida & Suberitidae & Suberitida & Suberitidae & 18S, 28S, mt, ESTs & yes \\
\hline Sulcastrella & 'Lithistida' & Desmanthidae & incertae sedis & & no & no \\
\hline Svenzea & Halichondrida & Scopalinidae & Scopalinida & Scopalinidae & $18 \mathrm{~S}, 28 \mathrm{~S}, \mathrm{COI}$ & yes \\
\hline Swartschewskia & Haplosclerida & Lubomirskiidae & Spongillida & Lubomirskiidae & $\begin{array}{l}\text { COI, 18S, 5.8S-ITS2-28S, } \\
\mathrm{mt}\end{array}$ & no \\
\hline Tectitethya & Hadromerida & Tethyidae & Tethyida & Tethyidae & no & yes \\
\hline Tedania & Poecilosclerida & Tedaniidae & Poecilosclerida & Tedaniidae & no & yes \\
\hline Tedaniphorbas & Poecilosclerida & Acarnidae & Poecilosclerida & Acarnidae & no & no \\
\hline Tentorina & Spirophorida & Spirasigmidae & $\begin{array}{l}\text { Tetractinellida } \\
\text { (Spirophorina) }\end{array}$ & Spirasigmidae & no & no \\
\hline Tentorium & Hadromerida & Polymastiidae & Polymastiida & Polymastiidae & $18 \mathrm{~S}$ & no \\
\hline Terpios & Hadromerida & Suberitidae & Suberitida & $\begin{array}{l}\text { Suberitida incertae } \\
\text { sedis }\end{array}$ & no & yes \\
\hline
\end{tabular}


Table 1 Listing of Heteroscleromorpha genera in alphabetical order (Continued)

\begin{tabular}{|c|c|c|c|c|c|c|}
\hline Tethya & Hadromerida & Tethyidae & Tethyida & Tethyidae & $18 \mathrm{~S}, 28 \mathrm{~S}, \mathrm{COI}$ & yes \\
\hline Tethyastra & Hadromerida & Tethyidae & Tethyida & Tethyidae & no & no \\
\hline Tethycometes & Hadromerida & Tethyidae & Tethyida & Tethyidae & no & no \\
\hline Tethyopsis & Astrophorida & Ancorinidae & $\begin{array}{l}\text { Tetractinellida } \\
\text { (Astrophorina) }\end{array}$ & Ancorinidae & no & yes \\
\hline Tethyspira & Halichondrida & Dictyonellidae & Axinellida & Raspailiidae & $18 \mathrm{~S}, 28 \mathrm{~S}, \mathrm{COI}$ & no \\
\hline Tethytimea & Hadromerida & Tethyidae & Tethyida & Tethyidae & no & yes \\
\hline Tetilla & Spirophorida & Tetillidae & $\begin{array}{l}\text { Tetractinellida } \\
\text { (Spirophorina) }\end{array}$ & Tetillidae & no & yes \\
\hline Tetrapocillon & Poecilosclerida & Guitarridae & Poecilosclerida & Guitarridae & no & yes \\
\hline Thenea & Astrophorida & Theneidae & $\begin{array}{l}\text { Tetractinellida } \\
\text { (Astrophorina) }\end{array}$ & Theneidae & $\mathrm{COI}, 28 \mathrm{~S}$ & yes \\
\hline Theonella & 'Lithistida' & Theonellidae & $\begin{array}{l}\text { Tetractinellida } \\
\text { (Astrophorina) }\end{array}$ & Theonellidae & COI, 28S, $18 \mathrm{~S}$ & yes \\
\hline Thoosa & Astrophorida & Thoosidae & $\begin{array}{l}\text { Tetractinellida } \\
\text { (Astrophorina) }\end{array}$ & Thoosidae & no & no \\
\hline Thrinacophora & Poecilosclerida & Raspailiidae & Axinellida & Raspailiidae & no & yes \\
\hline Thrombus & Astrophorida & Thrombidae & $\begin{array}{l}\text { Tetractinellida } \\
\text { (Astrophorina) }\end{array}$ & Thrombidae & 285 & no \\
\hline Timea & Hadromerida & Timeidae & Tethyida & Tethyidae & no & yes \\
\hline Topsentia & Halichondrida & Halichondriidae & Suberitida & $\begin{array}{l}\text { Suberitida incertae } \\
\text { sedis }\end{array}$ & no & yes \\
\hline Trachostylea & Poecilosclerida & Raspailiidae & Axinellida & Raspailiidae & no & no \\
\hline Trachycladus & Hadromerida & Trachycladidae & Trachycladida & Trachycladidae & $18 \mathrm{~S}, 28 \mathrm{~S}$ & yes \\
\hline Trachyteleia & Hadromerida & Polymastiidae & Polymastiida & Polymastiidae & no & no \\
\hline Tribrachium & Astrophorida & Ancorinidae & $\begin{array}{l}\text { Tetractinellida } \\
\text { (Astrophorina) }\end{array}$ & Ancorinidae & no & no \\
\hline Trikentrion & Poecilosclerida & Raspailiidae & Axinellida & Raspailiidae & no & yes \\
\hline Triptolemma & Astrophorida & Pachastrellidae & $\begin{array}{l}\text { Tetractinellida } \\
\text { (Astrophorina) }\end{array}$ & Pachastrellidae & no & yes \\
\hline Trochospongilla & Haplosclerida & Spongillidae & Spongillida & Spongillidae & no & yes \\
\hline Tsitsikamma & Poecilosclerida & Latrunculiidae & Poecilosclerida & Latrunculiidae & $18 \mathrm{~S}, \mathrm{COI}$ & no \\
\hline Tylexocladus & Hadromerida & Polymastiidae & Polymastiida & Polymastiidae & no & no \\
\hline Ulosa & Poecilosclerida & Esperiopsidae & Poecilosclerida ${ }^{2}$ & Esperiopsidae $^{2}$ & no & yes \\
\hline Umborotula & Haplosclerida & Spongillidae & Spongillida & Spongillidae & no & no \\
\hline Uritaia & Halichondrida & Halichondriidae & Suberitida & Halichondriidae & no & no \\
\hline Uruguaya & Haplosclerida & Potamolepidae & Spongillida & Potamolepidae & no & no \\
\hline Uruguayella & Haplosclerida & Spongillidae & Spongillida & Spongillidae & no & no \\
\hline Vetulina & 'Lithistida' & Vetulinidae & Sphaerocladina & Vetulinidae & 185 & yes \\
\hline Volzia & Hadromerida & Clionaidae & Clionaida & Clionaidae & no & no \\
\hline Vosmaeria & Halichondrida & Halichondriidae & Suberitida & Halichondriidae & 285 & no \\
\hline Vulcanella & Astrophorida & Vulcanellidae & $\begin{array}{l}\text { Tetractinellida } \\
\text { (Astrophorina) }\end{array}$ & Vulcanellidae & no & yes \\
\hline Waltherarndtia & Poecilosclerida & Raspailiidae & Axinellida & Raspailiidae & no & no \\
\hline Weberella & Hadromerida & Polymastiidae & Polymastiida & Polymastiidae & no & no \\
\hline Wigginsia & Poecilosclerida & Acarnidae & Poecilosclerida & Acarnidae & no & no \\
\hline Willardia & Hadromerida & Acanthochaetetidae & Clionaida & Acanthochaetetidae & no & no \\
\hline Xenospongia & Hadromerida & Tethyidae & Tethyida & Tethyidae & 185,285 & no \\
\hline
\end{tabular}


Table 1 Listing of Heteroscleromorpha genera in alphabetical order (Continued)

\begin{tabular}{|c|c|c|c|c|c|c|}
\hline Yucatania & Astrophorida & Thrombidae & $\begin{array}{l}\text { Tetractinellida } \\
\text { (Astrophorina) }\end{array}$ & Thrombidae & no & no \\
\hline Zyzzya & Poecilosclerida & Acarnidae & Poecilosclerida & Acarnidae & no & yes \\
\hline
\end{tabular}

\section{Competing interests}

The authors declare that they have no competing interests.

\section{Authors' contributions}

CM and PC equally contributed in conceiving and writing the paper. Both authors read and approved the final manuscript.

\section{Authors' information}

CM and PC are both sponge taxonomists and phylogeneticists publishing species descriptions and group revisions combining molecular and morphological data.

\section{Acknowledgements}

We warmly thank the organizers of the 9th International Sponge Conference (Fremantle, Western Australia, 4-8 Nov. 2013) for facilitating an informal and yet fruitful discussion on the need for a revised classification of Demospongiae. We also thank the organizers (Hans Tore Rapp and Joana Xavier (University of Bergen)) and participants of the 2nd International Workshop on Taxonomy of Atlanto-Mediterranean Deep-Sea Sponges (Bergen, Norway, 2-6 June 2014) for their comments on a first draft of this proposal. Andrzej Pisera is thanked for pointing out at this workshop the availability of the order name Sphaerocladina to welcome the Vetulinidae. Christine Schönberg is thanked for suggesting the name Clionaida. We thank Rob van Soest, Jean Vacelet, Nicole Boury-Esnault, John Hooper and one anonymous reviewer for their comments, which improved this manuscript. PC received support from the 'Swedish Taxonomy Initiative' project (dha 154/2011) and from the EU project 'BlueGenics' KBBE2012-6. CM received funding from the Beaufort Marine Biodiscovery Research Award under the Sea Change Strategy for Science Technology and Innovation (2006-2013).

\section{Author details}

'Queen's University Belfast, Marine Laboratory, Portaferry BT22 1PF, Northern Ireland, UK. ²Department of Organismal Biology, Division of Systematic Biology, Evolutionary Biology Centre, Uppsala University, Norbyvägen 18D, 75236 Uppsala, Sweden. ${ }^{3}$ Department of Medicinal Chemistry, Division of Pharmacognosy, BioMedical Centre, Husargatan 3, Uppsala University, 75123 Uppsala, Sweden.

Received: 30 November 2014 Accepted: 12 March 2015

Published online: 01 April 2015

\section{References}

1. Hooper JNA, van Soest RWM. Systema Porifera: A guide to the classification of sponges. New York: Kluwer Academic / Plenum Publishers; 2002

2. Wörheide G, Dohrmann M, Erpenbeck D, Larroux C, Maldonado M, Voigt O, et al. Deep Phylogeny and Evolution of Sponges (Phylum Porifera). Adv Mar Biol. 2012;61:1-78.

3. Cárdenas P, Pérez T, Boury-Esnault N. Sponge Systematics facing new challenges. Adv Mar Biol. 2012;61:79-209.

4. World Porifera database, http://www.marinespecies.org/porifera [http:// www.marinespecies.org/porifera]

5. Morrow CC, Picton BE, Erpenbeck D, Boury-Esnault N, Maggs CA, Allcock AL. Congruence between nuclear and mitochondrial genes in Demospongiae: A new hypothesis for relationships within the G4 clade (Porifera: Demospongiae). Mol Phylogen Evol. 2012:62:174-90.

6. Cárdenas P, Xavier JR, Reveillaud J, Schander C, Rapp HT. Molecular phylogeny of the Astrophorida (Porifera, Demospongiae) reveals an unexpected high level of spicule homoplasy. PLoS One. 2011;6:e18318.
7. Vargas S, Erpenbeck D, Göcke C, Hall KA, Hooper JNA, Janussen D, et al. Molecular phylogeny of Abyssocladia (Cladorhizidae: Poecilosclerida) and Phelloderma (Phellodermidae: Poecilosclerida) suggests a diversification of chelae microscleres in cladorhizid sponges. Zool Scr. 2013;42:106-16.

8. Erpenbeck D, Breeuwer JAJ, Parra-Velandia FJ, van Soest RWM. Speculation with spiculation? - Three independent gene fragments and biochemical characters versus morphology in demosponge higher classification. Mol Phylogen Evol. 2006;38:293-305.

9. Morrow CC, Redmond NE, Picton BE, Thacker RW, Collins AG, Maggs CA, et al. Molecular Phylogenies Support Homoplasy of Multiple Morphological Characters Used in the Taxonomy of Heteroscleromorpha (Porifera: Demospongiae). Integr Comp Biol. 2013;53:428-46.

10. Redmond NE, Morrow CC, Thacker RW, Diaz MC, Boury-Esnault N, Cárdenas $P$, et al. Phylogeny and Systematics of Demospongiae in Light of New Small Subunit Ribosomal DNA (18S) Sequences. Integr Comp Biol. 2013;53:388-415.

11. Hooper JNA, van Soest RWM. Class Demospongiae Sollas, 1885. In: Hooper JNA, van Soest RWM, editors. Systema Porifera: A guide to the classification of sponges. Volume 1. New York: Kluwer Academic/Plenum Publishers; 2002. p. 15-8.

12. Borchiellini C, Chombard C, Manuel M, Alivon E, Vacelet J, Boury-Esnault N. Molecular phylogeny of Demospongiae: implications for classification and scenarios of character evolution. Mol Phylogen Evol. 2004;32:823-37.

13. Thacker RW, Hill AL, Hill MS, Redmond NE, Collins AG, Morrow CC, et al. Nearly Complete 28S rRNA Gene Sequences Confirm New Hypotheses of Sponge Evolution. Integr Comp Biol. 2013;53:373-87.

14. Lavrov DV, Wang X, Kelly M. Reconstructing ordinal relationships in the Demospongiae using mitochondrial genomic data. Mol Phylogen Evol. 2008;49:111-24

15. Kayal E: The evolution of the mitochondrial genomes of calcareous sponges and cnidarians. PhD thesis. Iowa State University, 2012.

16. Lévi C. Ontogeny and Systematics in Sponges. Syst Zool. 1957;6:174-83.

17. Lévi C. Sur une nouvelle classification des Démosponges. Compte rendu hebdomadaire des séances de l'Académie des sciences. 1953;236:853-5.

18. van Soest RWM. Toward a phylogenetic classification of sponges. In: Rützler K, editor. New Perspectives in Sponge Biology. Washington: Smithsonian Institution; 1990. p. 344-8.

19. van Soest RWM. Demosponge higher taxa classification re-examined. In: Reitner J, Keupp H, editors. Fossil and recent sponges. Berlin Heidelberg: Springer Verlab; 1991. p. 54-71.

20. Lévi C. Systématique de la classe des Demospongiaria (Démosponges). In: Grassé PP, editor. Traité de Zoologie Spongiaires, vol. 3. Paris: Masson \& Co; 1973. p. 577-632.

21. Gazave E, Lapébie P, Ereskovsky A, Vacelet J, Renard E, Cárdenas P, et al. No longer Demospongiae: Homoscleromorpha formal nomination as a fourth class of Porifera. Hydrobiologia. 2012;687:3-10.

22. Nichols SA. An evaluation of support for order-level monophyly and interrelationships within the class Demospongiae using partial data from the large subunit rDNA and cytochrome oxidase subunit I. Mol Phylogen Evol. 2005;34:81-96

23. Boury-Esnault N. Systematics and evolution of Demospongiae. Can J Zool. 2006:84:205-24

24. Hill MS, Hill AL, Lopez J, Peterson KJ, Pomponi S, Diaz MC, et al. Reconstruction of Family-Level Phylogenetic Relationships within Demospongiae (Porifera) Using Nuclear Encoded Housekeeping Genes. PLoS One. 2013;8:e50437.

25. Erpenbeck D, Sutcliffe P, Cook SC, Dietzel A, Maldonado M, van Soest RWM, et al. Horny sponges and their affairs: On the phylogenetic relationships of keratose sponges. Mol Phylogen Evol. 2012;63:809-16. 
26. Ereskovsky AV, Lavrov DV, Boury-Esnault N, Vacelet J. Molecular and morphological description of a new species of Halisarca (Demospongiae: Halisarcida) from Mediterranean Sea and a redescription of the type species Halisarca dujardini. Zootaxa. 2011;2768:5-31.

27. Vacelet J, Donadey C. A new species of Halisarca (Porifera, Demospongiae) from the Caribbean, with remarks on the cytology and affinities of the genus. In: Jones WC, editor. European contributions to the taxonomy of sponges. Midleton: Litho Press Co; 1987. p. 5-12.

28. Vacelet J, Recent 'Sphinctozoa'. Family Verticillitidae Steinmann, 1882. In: Hooper JNA, van Soest RWM, editors. Systema Porifera: A Guide to the Classification of Sponges, vol. 1. New York: Kluwer Academic/Plenum Publishers; 2002. p. 1109-10.

29. Wörheide G. A hypercalcified sponge with soft relatives: Vaceletia is a keratose demosponge. Mol Phylogen Evol. 2008:47:433-8.

30. Wang X, Lavrov DV. Seventeen New Complete mtDNA Sequences Reveal Extensive Mitochondrial Genome Evolution within the Demospongiae. PLoS One. 2008;3:e2723.

31. West RR, Vacelet J, Wood RA, Willenz P, Hartman WD. Hypercalcified extant and fossil chaetetid-type and Post- Devonian stromatoporoid-type Demospongiae: Systematic descriptions. In: Treatise on Invertebrate Paleontology On Line, number 58 Part E, Revised. Lawrence, Kansas, USA: The University of Kansas, Paleontological Institute; 2013. p. 1-95.

32. Reitner J, Engeser TS. Revision der Demospongier mit einem thalamiden aragonitischen basaskelett und trabekulärer internstruktur ('Sphinctozoa' pars). Geowissenschaftliche Abhandlungen Reihe A (Geologie und Paläontologie). 1985;60:151-93.

33. Sperling EA, Peterson KJ, Pisani D. Phylogenetic-Signal Dissection of Nuclear Housekeeping Genes Supports the Paraphyly of Sponges and the Monophyly of Eumetazoa. Mol Biol Evol. 2009;26:2261-74.

34. Addis JS, Peterson KJ. Phylogenetic relationships of freshwater sponges (Porifera, Spongillina) inferred from analyses of $18 \mathrm{~S}$ rDNA, COI mtDNA, and ITS2 rDNA sequences. Zool Scr. 2005;34:549-57.

35. Pisera A, Lévi C. 'Lithistid' Demospongiae. In: Hooper JNA, van Soest RWM, editors. Systema Porifera: A Guide to the classification of Sponges. New York: Kluwer Academic / Plenum Publishers; 2002. p. 299-301.

36. Schuster A, Erpenbeck D, Pisera A, Hooper JNA, Bryce M, Fromont J, et al. Deceptive desmas: molecular phylogenetics suggests a new classification and uncovers convergent evolution of lithistid demosponges. PLoS One. 2015;10(1):e116038.

37. Hajdu E, van Soest RWM, Hooper JNA. Proposal for a phylogenetic subordinal classification of poecilosclerid sponges. In: van Soest RWM, van Kempen TMG Braekman J-C, editors. Sponges in Time and Space. Rotterdam: Balkema; 1994 p. $123-39$

38. Hajdu E, de Paula TS, Redmond NE, Cosme B, Collins AG, Lôbo-Hajdu G. Mycalina: Another Crack in the Poecilosclerida Framework. Integr Comp Biol. 2013;53:462-72.

39. Erpenbeck D, Hall K, Alvarez B, Büttner G, Sacher K, Schätzle S, et al. The phylogeny of halichondrid demosponges: past and present re-visited with DNA-barcoding data. Org Divers Evol. 2012;12:57-70.

40. Erpenbeck D, van Soest RWM. A survey for biochemical synapomorphies to reveal phylogenetic relationships of halichondrid demosponges (Metazoa: Porifera). Biochem Syst Ecol. 2005;33:585-616.

41. Chombard C: Les Demospongiae à asters: phylogénie moléculaire et homologie morphologique. Ph.D thesis. Muséum National d'Histoire Naturelle, 1998.

42. Chombard C, Boury-Esnault N. Good congruence between morphology and molecular phylogeny of Hadromerida, or how to bother sponge taxonomists [abstract]. Mem Queensl Mus. 1999;44:100.

43. Maldonado M. Embryonic development of verongid demosponges supports the independent acquisition of spongin skeletons as an alternative to the siliceous skeleton of sponges. Biol J Linn Soc. 2009;97:427-47.

44. Haeckel E. Generelle Morphologie der Organismen. Allgemeine grundzüge der organischen formen-wissenschaft, mechanisch begründet durch die von Charles Darwin reformirte descendenztheorie. Band 2. Berlin: Geork Reimer; 1866.

45. Bergquist PR, Cook SDC. Order Verongida Bergquist, 1978. In: Hooper JNA, van Soest RWM, editors. Systema Porifera: A Guide to the Classification of Sponges, vol. 1. New York: Kluwer Academic/Plenum Publishers; 2002. p. 1081

46. Erwin PM, Thacker RW. Phylogenetic analyses of marine sponges within the order Verongida: a comparison of morphological and molecular data. Invertebr Biol. 2007;126:220-34.
47. Diaz MC, Thacker RW, Redmond NE, Matterson KO, Collins AG. Phylogenetic Novelties and Geographic Anomalies among Tropical Verongida. Integr Comp Biol. 2013;53:482-94.

48. Bergquist PR, Cook SDC. Order Dendroceratida Minchin, 1900. In: Hooper JNA van Soest RWM, editors. Systema Porifera: A Guide to the Classification of Sponges, vol. 1. New York: Kluwer Academic/Plenum Publishers; 2002. p. 1067.

49. Cook SDC, Bergquist PR. Order Dictyoceratida Minchin, 1900. In: Hooper JNA, van Soest RWM, editors. Systema Porifera: A Guide to the Classification of Sponges, vol. 1. New York: Kluwer Academic/Plenum Publishers; 2002. p. 1021.

50. Manconi R, Pronzato R. Suborder Spongillina subord. nov.: Freshwater Sponges. In: Hooper JNA, van Soest RWM, editors. Systema Porifera: A Guide to the classification of Sponges, vol. 1. New York: Kluwer Academic/Plenum Publishers; 2002. p. 921-1020.

51. Itskovich V, Kaluzhnaya O, Ostrovsky I, McCormack G. The number of endemic species of freshwater sponges (Malawispongiidae; Spongillina; Porifera) from Lake Kinneret is overestimated. J Zool Syst Evol Res. 2013;51:252-7.

52. Harcet M, Bilandžija H, Bruvo-Mađarić B, Cetković H. Taxonomic position of Eunapius subterraneus (Porifera, Spongillidae) inferred from molecular data - A revised classification needed? Mol Phylogen Evol. 2010;54:1021-7.

53. Erpenbeck D, Weier T, de Voogd NJ, Wörheide G, Sutcliffe P, Todd JA, et al. Insights into the evolution of freshwater sponges (Porifera: Demospongiae: Spongillina): Barcoding and phylogenetic data from Lake Tanganyika endemics indicate multiple invasions and unsettle existing taxonomy. Mol Phylogen Evol. 2011;61:231-6.

54. Lundbeck W. Porifera. (Part I.) Homorrhaphidae and Heterorrhaphidae. In: The Danish Ingolf-Expedition 6(1). Copenhagen: Bianco Luno; 1902.

55. Vacelet J. Éponges de la Roche du Large et de l'étage bathyal de Méditerranée (Récoltes de la soucoupe plongeante Cousteau et dragages). Mémoires du Muséum national d'Histoire naturelle (A, Zoologie). 1969;59:145-219. pls I-IV.

56. Pisera A, Lévi C. Family Vetulinidae Lendenfeld, 1903. In: Hooper JNA, van Soest RWM, editors. Systema Porifera: A Guide to the classification of Sponges, vol. 1. New York: Kluwer Academic/Plenum Publishers; 2002. p. 363-5.

57. Bergquist PR. Additions to the Sponge Fauna of the Hawaiian Islands. Micronesica. 1967;3:159-74.

58. Bergquist PR. The Marine Fauna of New Zealand: Porifera, Demospongiae, Part 2 (Axinellida and Halichondrida). New Zealand Department of Scientific and Industrial Research Bulletin [New Zealand Oceanographic Institute Memoir 51]. 1970;197:1-85.

59. Hall KA, Ekins MG, Hooper JNA. Two new desma-less species of Theonella Gray, 1868 (Demospongiae: Astrophorida: Theonellidae), from the Great Barrier Reef, Australia, and a re-evaluation of one species assigned previously to Dercitus Gray, 1867. Zootaxa. 2013;3814:451-77.

60. Cedro VR, Hajdu E, Correia MD. Three new intertidal sponges (Porifera: Demospongiae) from Brazil's fringing urban reefs (Maceió, Alagoas, Brazil), and support for Rhabderemia's exclusion from Poecilosclerida. J Nat Hist. 2013;47:2151-74.

61. van Soest RWM, Hooper JNA. Taxonomy, phylogeny and biogeography of the marine sponge genus Rhabderemia Topsent, 1890 (Demospongiae, Poecilosclerida). Scientia Marina. 1993;57:319-51.

62. Chombard C, Boury-Esnault N, Tillier S. Reassessment of homology of morphological characters in Tetractinellid sponges based on molecular data. Syst Biol. 1998:47:351-66.

63. Cárdenas P, Rapp HT, Schander C, Tendal OS. Molecular taxonomy and phylogeny of the Geodiidae (Porifera, Demospongiae, Astrophorida) combining phylogenetic and Linnaean classification. Zool Scr. 2010;39:89-106

64. Gazave E, Carteron S, Chenuil A, Richelle-Maurer E, Boury-Esnault N, Borchiellini C. Polyphyly of the genus Axinella and of the family Axinellidae (Porifera: Demospongiaep). Mol Phylogen Evol. 2010;57:35-47.

65. Boury-Esnault N. Family Polymastiidae Gray, 1867. In: Hooper JNA, van Soest RWM, editors. Systema Porifera: A Guide to the classification of Sponges, vol. 1. New York: Kluwer Academic/Plenum Publishers; 2002. p. 201-19.

66. Vacelet J. Description et affinités d'une éponge sphinctozoaire actuelle. In: Lévi C, Boury-Esnault N, editors. Biologie des Spongiaires - Sponge Biology Colloques Internationaux du Centre National de la Recherche Scientifique, 291. Paris: Editions du CNRS; 1979. p. 483-93.

67. Vacelet J. Eponges hypercalcifiées ("Pharétronides", "Sclérosponges") des cavités des récifs coralliens de Nouvelle-Calédonie. Bulletin du Muséum National d'Histoire Naturelle. 1981;3:313-51. 
68. Hajdu E, van Soest RWM. Family Merliidae Kirkpatrick, 1908. In: Hooper JNA, van Soest RWM, editors. Systema Porifera: A Guide to the classification of Sponges, vol. 1. New York: Kluwer Academic / Plenum Publishers; 2002. p. 691-3.

69. Topsent E. Spongiaires de l'Atlantique et de la Méditerranée provenant des croisières du Prince Albert ler de Monaco. Résultats des campagnes scientifiques accomplies par le Prince Albert I Monaco. 1928;74:1-376. pls I-XI.

70. Hajdu E, van Soest RWM. Family Desmacellidae Ridley \& Dendy, 1886. In: Hooper JNA, van Soest RWM, editors. Systema Porifera: A Guide to the classification of Sponges, vol. 1. New York: Kluwer Academic/Plenum Publishers; 2002. p. 642-50.

71. Hooper JNA, van Soest RWM. Order Poecilosclerida Topsent, 1928. In: Hooper JNA, van Soest RWM, editors. Systema Porifera: A Guide to the classification of Sponges, vol. 1. New York: Kluwer Academic/Plenum Publishers; 2002. p. 403-8.

72. Barucca M, Azzini F, Bavestrello G, Biscotti M, Calcinai B, Canapa A, et al. The systematic position of some boring sponges (Demospongiae, Hadromerida) studied by molecular analysis. Mar Biol. 2007;151:529-35.

73. Hooper JNA, van Soest RWM. Family Trachycladidae Hallmann, 1917. In: Hooper JNA, van Soest RWM, editors. Systema Porifera: A Guide to the classification of Sponges, vol. 1. New York: Kluwer Academic/Plenum Publishers; 2002. p. 268-74.

74. Ridley SO, Dendy A, Report on the Monaxonida collected by H.M.S. 'Challenger' during the years 1873-1876. Report on the Scientific Results of the Voyage of HMS 'Challenger', 1873-1876 Zoology. 1887;20(59):i-Ixviii-1-275, pls I-LI.

75. Vosmaer GCJ: Klassen und Ordnungen der Spongien (Porifera). In Die Klassen und Ordnungen des Thierreichs 2. Edited by Bronn HG: Leipzig \& Heidelberg; 1887: i-xii, 1-496, pls I-XXXIV

76. Pisera A, Lévi C. "Lithistids" Incertae Sedis. In: Hooper JNA, van Soest RWM, editors. Systema Porifera: A Guide to the classification of Sponges. New York: Kluwer Academic / Plenum Publishers; 2002. p. 384-7.

77. Vacelet J, Perez T, Hooper JNA. Demospongiae incertae sedis: Myceliospongia Vacelet and Perez, 1998. In: Hooper JNA, van Soest RWM, editors. Systema Porifera: A Guide to the classification of Sponges, vol. 1. New York: Kluwer Academic / Plenum Publishers; 2002. p. 1099-101.

78. Dominguez E, Wheeler QD. Taxonomic Stability is Ignorance. Cladistics. 1997;13:367-72.

\section{Submit your next manuscript to BioMed Central and take full advantage of:}

- Convenient online submission

- Thorough peer review

- No space constraints or color figure charges

- Immediate publication on acceptance

- Inclusion in PubMed, CAS, Scopus and Google Scholar

- Research which is freely available for redistribution 